\title{
Hygrophorus russula complex (Hygrophoraceae, Agaricales) in China
}

Hong-Yan Huang ( $\square$ 932235661@qq.com )

Kunming Medical University https://orcid.org/0000-0003-4028-3124

\section{Wen-Hao Zhang}

Kunming Medical University

\section{Ting Huang}

Kunming Medical University

\section{Moreno Gabriel}

Universidad de Alcalá de Henares: Universidad de Alcala de Henares

Tie-Zhi Liu

Chifeng University

\section{Li-Ping Tang}

Kunming Medical University

\section{Research Article}

Keywords: Hygrophoraceae, taxonomy, cryptic species, molecular systematics

Posted Date: February 25th, 2021

DOI: https://doi.org/10.21203/rs.3.rs-190507/v1

License: (ㅇ) (1) This work is licensed under a Creative Commons Attribution 4.0 International License. Read Full License 


\section{Abstract}

The Chinese species complex of Hygrophorus russula in subsection Clitocyboides has been studied. Three new species, H. orientalis, $H$. qinggangjun and $H$. yunnanensis were proposed, based on morphology, molecular systematics and chemical reactions.

Hygrophorus qinggangjun and $H$. yunnanensis occur at high elevations of Yunnan China; $H$. orientalis is widely distributed in East Asia and occurs at low elevations. At present, seven taxa have been revealed in the $H$. russula species complex; a key to these species is provided.

\section{Introduction}

The genus Hygrophorus Fr. (Hygrophoraceae, Agaricales) contains around 270 species, based on the Index Fungorum (http://www.indexfungorum.org). Most species are widespread in the temperate regions of the Northern Hemisphere (Tedersoo et al. 2010) and are characterised by sub-viscid to glutinous pileus, adnate to decurrent lamellae and divergent hymenophoral trama (Hesler and Smith 1963; Bas et al. 1990; Candusso 1997; Lodge et al. 2014). Species of Hygrophorus are ectomycorrhizal, excluding a couple of parasitic species, such as H. olivaceoalbus (Fr.) Fr. and H. penarius Fr. (Marino 2008; Agerer 2012), but possibly behave as facultative ectomycorrhizal species. Most form associations with both broad-leaved and coniferous trees. Many appear to show host preference: for example, H. alboflavescens A. Naseer \& A.N. Khalid forms ectomycorrhizal associations with Quercus incana (Naseer et al. 2019); H. betulae K. Bendiksen \& E. Larss. is associated with Betula pubescens (Larsson and Bendiksen 2020); H. boyeri Lebeuf, Bellanger \& H. Lambert and H. meridionalis Loizides, P.-A. Moreau, Athanassiou \& Athanasiades are found in pine forests (Moreau et al. 2018); H. russuliformis Murrill occurs with oak in Florida (Hesler and Smith 1963); H. yadigarii E. Sesli, Antonín \& Contu occurs in hornbeam-spruce-dominated forests (Sesli et al. 2018) and H. yukishiro N. Endo, Tokoo \& A. Yamada grows on the ground of oak forests (Quercus acutissima and Quercus serrata) (Endo et al. 2018).

Recently, Lodge et al. (2014) proposed the infrageneric updates of Hygrophorus, based on molecular phylogeny and revealed, in many cases, that the same name has been widely applied while presenting several different phylogenetic species. Other studies uncovered hidden diversity in North America and Europe: for example, H. hypothejus (Fr.) Fr. complex in section Aurei (Bataille) E. Larss. (Moreau et al. 2018) and H. agathosmus (Fr.) Fr. group in subsection Tephroleuci (Bataille) Singer (Larsson et al. 2018).

Hygrophorus russula (Schaeff. ex Fr.) Kauffman, originally from Europe, (Schaeffer 1774) belongs to subsection Clitocyboides (Hesler \& A.H. Sm.) E. Larss and is characterised by a pinkish-red to vinaceous-purple pileus. This name has been widely used for some similar species found in Africa (GenBank sequence KU973852), Asia (Hongo 1982; Chen and Li 2013), North America (Hesler and Smith 1963; Siegel and Schwarz 2016) and South America (GenBank sequence KF381523). Recent studies indicate that this name harbours at least a couple of new taxa in Asia, viz. H. deliciosus C.Q. Wang \& T.H. Li and H. parvirussula H.Y. Huang \& L.P. Tang, both from southwestern China (Huang et al. 2018; Wang and Li 2020). These results indicated that the species diversity within Hygrophorus is higher than previous estimates.

In order to explore the genetic diversity, host preference and geographic distribution of the H. russula complex, we studied more than 80 well-documented specimens from China. Based on morphological characters, chemical reactions and phylogenetic results, along with sequences of this species complex from GenBank, three species are proposed as new: $H$. qinggangjun and $H$. yunnanensis from southwestern China and $H$. orientalis widely distributed in East Asia.

\section{Materials And Methods}

\section{Sampling and morphological studies}

Most specimens were collected in central (Hubei), northern and south-western China during rainy seasons (July-October). Basidiomes were found in broad-leaved forests, mainly Ericaceae and Fagaceae. Herbarium materials, identified as $H$. russula, were loaned from the University of Alcalá (AH). Other specimens were deposited in the Herbarium of Cryptogams, Kunming Institute of Botany, Chinese Academy of Sciences (HKAS), the Mycological Herbarium, Institute of Mycology, Chinese Academy of Sciences (HMAS), the Mycological Herbarium of Kunming Medical University (MHKMU) and the Herbarium of the Royal Botanic Garden, Edinburgh (RBGE).

Macro-morphological descriptions were taken from field notes and images of basidiomes, with colour codes following Kornerup and Wanscher (1981). Micro-morphological characters were observed from dried materials after being sectioned and mounted in $5 \%$ potassium hydroxide $(\mathrm{KOH})$ and 1\% Congo Red solution (w/v) under a Leica DM2500 microscope. Melzer's Reagent was used to test 
the amyloidy of basidiospores. Basidiospores and hyphae of the basal mycelium were examined with a ZEISS Sigma 300 scanning electron microscope (SEM) at $7.00 \mathrm{kV}$. The procedures followed those in Huang et al. $(2018,2020)$ and are referenced therein. The following abbreviations $[\mathrm{n} / \mathrm{m} / \mathrm{p}]$ indicate $\mathrm{n}$ basidiospores measured from $\mathrm{m}$ basidiomes of $\mathrm{p}$ collections. Dimensions for basidiospores are given using (a) b-c (d), the range of b-c contains a minimum of $90 \%$ of the measured values and ' $a$ ' and ' $d$ ' were the extreme values. $\mathrm{Q}$ means the quotient of length and width in the side view of basidiospores and $\mathrm{Q}_{\mathrm{m}}$ indicates average $\mathrm{Q}$ of all basidiospores \pm sample standard deviation.

Chemical reactions

Seven chemical reagents were applied in this study: $\mathrm{C}_{6} \mathrm{H}_{5} \mathrm{OH}=10 \%(\mathrm{w} / \mathrm{v})$ phenol, $\mathrm{EtOH}=95 \%(\mathrm{w} / \mathrm{v})$ ethanol, $\mathrm{FeCl}_{3}=10 \%(\mathrm{w} / \mathrm{v})$ ferric chloride, $\mathrm{FeSO}_{4}=10 \%(\mathrm{w} / \mathrm{v})$ ferrous sulphate, $\mathrm{KOH}=5 \%(\mathrm{w} / \mathrm{v})$ potassium hydroxide, Melzer's $=$ Melzer's Reagent, $\mathrm{NH}_{4} \mathrm{OH}=10 \%(\mathrm{w} / \mathrm{v})$ ammonium hydroxide. A piece of tissue was taken separately from the pilei, context, lamellae and stipes of dried basidiocarps. Colour changes were recorded following the application of reagents.

DNA extraction, PCR amplification and sequencing

Total genomic DNA was extracted from about 10-20 mg of dried basidiome tissue using a modified CTAB method (Doyle 1987). ITS regions and large subunit nuclear ribosomal RNA (nrLSU) region were amplified by a polymerase chain reaction (PCR) using primer pairs ITS5/ITS4 and LROR/LR5 (Vilgalys and Hester 1990; White et al. 1990). PCR reactions were performed in $25 \mu$ reaction mixtures containing $2.5 \mu \mathrm{l}$ of $10 \times$ amplification buffer (with $\left.\mathrm{MgCl}_{2}\right), 0.5 \mu \mathrm{lNTP}(200 \mu \mathrm{M}), 0.2 \mu \mathrm{l}$ Taq DNA polymerase $(5 \mathrm{U} / \mu \mathrm{l}), 1 \mu \mathrm{l}$ of each primer $(10 \mu \mathrm{M}), 1 \mu \mathrm{l}$ DNA template and $18.8 \mu \mathrm{l}$ sterile water. PCR conditions followed the programme of Yang et al. (2018). PCR products were checked on 1\% agarose gels. Amplified PCR products were sequenced using an ABI 3730 DNA Analyzer (Sangon, Shanghai, China) with the same primers.

Sequence alignment and phylogenetic analyses

Raw sequences were assembled and edited using SeqMan (DNASTAR Lasergene 9) and deposited in GenBank (http://www.ncbi.nlm.nih.gov) (see Table 1). DNA sequences of ITS and nrLSU were independently aligned using MUSCLE 3.6 (Edgar 2004) and manually adjusted where necessary in BioEdit 7.0.9 (Hall 1999); the concatenated datasets were manually constructed. The dataset was analysed with Maximum Likelihood (ML) and Bayesian Inference (BI). ML analyses were performed using RAxML 7.0.3 (Stamatakis et al. 2008); GTRGAMMA was set by default as the selected model; statistical support of clades was obtained with 1000 rapid bootstrap replicates. For BI, concatenated sequences were partitioned into ITS1 (1-140), 5.8S (141-309), ITS2 (310-588) and LSU (589-1471). The best-fit model of nucleotide substitution was obtained in PartitionFinder 2 (Lanfear et al. 2016), based on the Akaike Information Criteria (AIC). The selected models were GTR $+\mathrm{G}$ for ITS1 and ITS2, K80 for 5.8S and GTR $+\mathrm{I}+\mathrm{G}$ for nrLSU. Partitioned Bayesian analysis was performed with MrBayes 3.2 (Ronquist et al. 2012) on the CIPRES portal. Four simultaneous Markov chains were run for $6,000,000$ generations for ITS and nrLSU, 8,000,000 generations for concatenated sequences and sampled every 1000 generations. At the end of the run, the average deviation of split frequencies was below 0.005 . Burn-in values were determined in Tracer 1.7 (Rambaut et al. 2018). The first $25 \%$ of generations were discarded as burn-in, when the plot generated by the sump command levelled off and effective sample sizes were well over 200 for all sampled parameters for each run. 
Table 1

Sequences used/produced in the present study

\begin{tabular}{|c|c|c|c|c|c|}
\hline Taxon & Voucher & Locality & $\begin{array}{l}\text { GenBank } \\
\text { Accession No. (ITS) }\end{array}$ & $\begin{array}{l}\text { GenBank Accession } \\
\text { No. (LSU) }\end{array}$ & References \\
\hline $\begin{array}{l}\text { Hygrophorus } \\
\text { deliciosus }\end{array}$ & ZJ0002LS04 & China, Sichuan & KU836534 & - & Liu et al. unpublished \\
\hline H. deliciosus & GDGM 79208 & China, Yunnan & МT363808 & - & Wang and Li 2020 \\
\hline H. deliciosus & HKAS 54703 & China, Yunnan & MW290158* & MW290225* & This study \\
\hline H. deliciosus & HKAS 51000 & China, Sichuan & MW290159* & MW290226* & This study \\
\hline H. deliciosus & HKAS 76246 & China, Sichuan & MW290160* & MW290227* & This study \\
\hline H. deliciosus & HKAS 69670 & China, Yunnan & MW290161* & MW290228* & This study \\
\hline H. deliciosus & HKAS 54510 & China, Yunnan & MW290162* & MW290229* & This study \\
\hline H. deliciosus & $\begin{array}{l}\text { MHKMU S.D. } \\
\text { Yang } 43\end{array}$ & China, Yunnan & MW290163* & MW290230* & This study \\
\hline H. deliciosus & HKAS 55053 & China, Yunnan & MW290164* & - & This study \\
\hline H. deliciosus & HKAS 61276 & China, Yunnan & MW290165* & MW290231* & This study \\
\hline H. deliciosus & HKAS 61315 & China, Yunnan & MW290166* & MW290232* & This study \\
\hline H. deliciosus & HKAS 71624 & China, Yunnan & MW290167* & - & This study \\
\hline H. deliciosus & HMAS 253198 & China, Tibet & MW290168* & - & This study \\
\hline H. deliciosus & HMAS 253233 & China, Tibet & MW290169* & MW290233* & This study \\
\hline H. deliciosus & HMAS 253249 & China, Tibet & MW290170* & MW290234* & This study \\
\hline H. deliciosus & $\begin{array}{l}\text { MHKMU H.Y. } \\
\text { Huang } 725\end{array}$ & China, Yunnan & MW290171* & - & This study \\
\hline H. deliciosus & $\begin{array}{l}\text { MHKMU H.Y. } \\
\text { Huang } 806\end{array}$ & China, Yunnan & MW290172* & MW290235* & This study \\
\hline H. deliciosus & $\begin{array}{l}\text { MHKMU H.Y. } \\
\text { Huang } 807\end{array}$ & China, Yunnan & MW290173* & MW290236* & This study \\
\hline H. deliciosus & $\begin{array}{l}\text { MHKMU H.Y. } \\
\text { Huang } 1006\end{array}$ & China, Yunnan & MW290174* & MW290237* & This study \\
\hline H. deliciosus & $\begin{array}{l}\text { MHKMU H.Y. } \\
\text { Huang } 1008\end{array}$ & China, Yunnan & MW290175* & MW290238* & This study \\
\hline $\begin{array}{l}\text { H. orientalis } \\
\text { (Holotype) }\end{array}$ & HKAS 75586 & China, Hubei & MW290176* & MW290239* & This study \\
\hline H. orientalis & HKAS 63417 & China, Jilin & MW290177* & MW290240* & This study \\
\hline H. orientalis & HKAS 71845 & China, Jilin & MW290178* & MW290241* & This study \\
\hline H. orientalis & HKAS 71851 & China, Shaanxi & MW290179* & MW290242* & This study \\
\hline H. orientalis & HKAS 58741 & China, Yunnan & MW290180* & MW290243* & This study \\
\hline H. orientalis & $\begin{array}{l}\text { MHKMU H.Y. } \\
\text { Huang } 472\end{array}$ & China, Jilin & MW290181* & - & This study \\
\hline H. orientalis & CFSZ 20884 & $\begin{array}{l}\text { China, Inner } \\
\text { Mongolia }\end{array}$ & MW290182* & - & This study \\
\hline H. parvirussula & HKAS 53605 & China, Sichuan & MH160768 & MH160772 & Huang et al. 2018 \\
\hline
\end{tabular}




\begin{tabular}{|c|c|c|c|c|c|}
\hline Taxon & Voucher & Locality & $\begin{array}{l}\text { GenBank } \\
\text { Accession No. (ITS) }\end{array}$ & $\begin{array}{l}\text { GenBank Accession } \\
\text { No. (LSU) }\end{array}$ & References \\
\hline H. parvirussula & $\begin{array}{l}\text { MHKMU L.P. } \\
\text { Tang } 1691\end{array}$ & China, Yunnan & MH160769 & MH160773 & Huang et al. 2018 \\
\hline H. parvirussula & $\begin{array}{l}\text { MHKMU N.K. } \\
\text { Zeng } 2878\end{array}$ & China, Yunnan & MH160770 & MH160774 & Huang et al. 2018 \\
\hline H. parvirussula & $\begin{array}{l}\text { MHKMU S.D. } \\
\text { Yang } 434\end{array}$ & China, Yunnan & MH160771 & MH160775 & Huang et al. 2018 \\
\hline H. parvirussula & HKAS 56191 & China, Yunnan & MW290183* & - & This study \\
\hline H. parvirussula & HKAS 57447 & China, Yunnan & MW290184* & - & This study \\
\hline H. parvirussula & HKAS 58821 & China, Yunnan & MW290185* & - & This study \\
\hline H. parvirussula & $\begin{array}{l}\text { MHKMU S.D. } \\
\text { Yang } 12\end{array}$ & China, Yunnan & MW290186* & MW290244* & This study \\
\hline H. parvirussula & $\begin{array}{l}\text { MHKMU W.H. } \\
\text { Zhang } 177\end{array}$ & China, Yunnan & MW290187* & MW290245* & This study \\
\hline H. parvirussula & $\begin{array}{l}\text { MHKMU W.H. } \\
\text { Zhang } 178\end{array}$ & China, Yunnan & MW290188* & MW290246* & This study \\
\hline H. parvirussula & $\begin{array}{l}\text { MHKMU W.H. } \\
\text { Zhang } 179\end{array}$ & China, Yunnan & MW290189* & MW290247* & This study \\
\hline H. parvirussula & $\begin{array}{l}\text { MHKMU T. } \\
\text { Huang } 220\end{array}$ & China, Yunnan & MW290190* & MW290248* & This study \\
\hline H. parvirussula & $\begin{array}{l}\text { MHKMU H.Y. } \\
\text { Huang } 501\end{array}$ & China, Yunnan & MW290191* & MW290249* & This study \\
\hline H. parvirussula & $\begin{array}{l}\text { MHKMU W.H. } \\
\text { Zhang } 183\end{array}$ & China, Yunnan & MW290192* & MW290250* & This study \\
\hline H. parvirussula & $\begin{array}{l}\text { MHKMU W.H. } \\
\text { Zhang } 195\end{array}$ & China, Yunnan & MW290193* & MW290251* & This study \\
\hline H. parvirussula & $\begin{array}{l}\text { MHKMU H.Y. } \\
\text { Huang } 534\end{array}$ & China, Yunnan & - & MW290252* & This study \\
\hline H. parvirussula & $\begin{array}{l}\text { MHKMU Y.J. Pu } \\
171\end{array}$ & China, Yunnan & MW290194* & MW290253* & This study \\
\hline H. parvirussula & $\begin{array}{l}\text { MHKMU H.Y. } \\
\text { Huang } 911\end{array}$ & China, Yunnan & MW290195* & MW290254* & This study \\
\hline H. parvirussula & $\begin{array}{l}\text { MHKMU L.P. } \\
\text { Tang } 3420\end{array}$ & China, Yunnan & MW290196* & MW290255* & This study \\
\hline H. parvirussula & $\begin{array}{l}\text { MHKMU T. } \\
\text { Huang } 455\end{array}$ & China, Yunnan & MW290197* & - & This study \\
\hline H. parvirussula & $\begin{array}{l}\text { MHKMU T. } \\
\text { Huang } 476\end{array}$ & China, Yunnan & - & - & This study \\
\hline H. parvirussula & $\begin{array}{l}\text { MHKMU T. } \\
\text { Huang } 491\end{array}$ & China, Yunnan & MW290198* & - & This study \\
\hline H. parvirussula & $\begin{array}{l}\text { MHKMU M. Mu } \\
770\end{array}$ & China, Yunnan & MW290199* & - & This study \\
\hline H. parvirussula & $\begin{array}{l}\text { MHKMU Y.J. Pu } \\
376\end{array}$ & China, Yunnan & MW290200* & MW290256* & This study \\
\hline H. parvirussula & $\begin{array}{l}\text { MHKMU Y.J. Pu } \\
399\end{array}$ & China, Yunnan & MW290201* & MW290257* & This study \\
\hline
\end{tabular}




\begin{tabular}{|c|c|c|c|c|c|}
\hline Taxon & Voucher & Locality & $\begin{array}{l}\text { GenBank } \\
\text { Accession No. (ITS) }\end{array}$ & $\begin{array}{l}\text { GenBank Accession } \\
\text { No. (LSU) }\end{array}$ & References \\
\hline H. parvirussula & $\begin{array}{l}\text { MHKMU W.H. } \\
\text { Zhang } 535\end{array}$ & China, Yunnan & MW290202* & MW290258* & This study \\
\hline H. parvirussula & $\begin{array}{l}\text { MHKMU T. } \\
\text { Huang } 516\end{array}$ & China, Yunnan & MW290203* & - & This study \\
\hline H. parvirussula & $\begin{array}{l}\text { MHKMU H.Y. } \\
\text { Huang } 1007\end{array}$ & China, Yunnan & MW290204* & MW290259* & This study \\
\hline H. penarioides & HGT 000921 & Sweden, Gotlands & EF395371 & - & $\begin{array}{l}\text { Jacobsson and } \\
\text { Larsson } 2007\end{array}$ \\
\hline H. qinggangjun & Zhao 447 & China, Yunnan & MW290147* & MW290218* & This study \\
\hline H. qinggangjun & HKAS 68397 & China, Yunnan & MW290148* & MW290219* & This study \\
\hline H. qinggangjun & $\begin{array}{l}\text { MHKMU S.D. } \\
\text { Yang } 20\end{array}$ & China, Yunnan & MW290149* & MW290220* & This study \\
\hline $\begin{array}{l}\text { H. qinggangjun } \\
\text { (Holotype) }\end{array}$ & $\begin{array}{l}\text { MHKMU L.P. } \\
\text { Tang } 1683\end{array}$ & China, Yunnan & MW290150* & MW290221* & This study \\
\hline H. qinggangjun & HKAS 55496 & China, Yunnan & MW290151* & - & This study \\
\hline H. qinggangjun & HKAS 60481 & China, Yunnan & MW290152* & - & This study \\
\hline H. qinggangjun & HKAS 60530 & China, Yunnan & MW290153* & - & This study \\
\hline H. qinggangjun & HKAS 72665 & China, Yunnan & MW290154* & - & This study \\
\hline H. qinggangjun & $\begin{array}{l}\text { MHKMU M. Mu } \\
464\end{array}$ & China, Yunnan & MW290155* & MW290222* & This study \\
\hline H. qinggangjun & $\begin{array}{l}\text { MHKMU M. Mu } \\
436\end{array}$ & China, Yunnan & MW290156* & MW290223* & This study \\
\hline H. qinggangjun & $\begin{array}{l}\text { MHKMU H.Y. } \\
\text { Huang } 724\end{array}$ & China, Yunnan & MW290157* & MW290224* & This study \\
\hline H. russula & AH 19677 & $\begin{array}{l}\text { Spain, } \\
\text { Torrelodones }\end{array}$ & MW290205* & MW290260* & This study \\
\hline H. russula & AH 37145 & Spain, Javierregay & MW290206* & MW290261* & This study \\
\hline H. russula & LAS 85196 & Sweden, - & EF395376 & - & $\begin{array}{l}\text { Jacobsson and } \\
\text { Larsson } 2007\end{array}$ \\
\hline H. russula & VAC 8b-09 & France, - & JF506764 & - & Shahin unpublished \\
\hline H. russula & 11936 & Italy, - & JF908065 & - & $\begin{array}{l}\text { Osmundson et al. } \\
2013\end{array}$ \\
\hline H. russula & 992 & Italy, - & JF908077 & - & $\begin{array}{l}\text { Osmundson et al. } \\
2013\end{array}$ \\
\hline H. russula & HE 2787 & - & KC505575 & - & Sun et al. unpublished \\
\hline H. russula & CFMR JP-3 & Japan, Shiga & KF291216 & - & Lodge et al. 2014 \\
\hline H. russula & CLO-4280 & $\begin{array}{l}\text { Belize, Mountain } \\
\text { Pine Ridge }\end{array}$ & KF381523 & - & Lodge et al. 2014 \\
\hline H. russula & GO-2009-116 & $\begin{array}{l}\text { Mexico, } \\
\text { Temascaltepec }\end{array}$ & KT875017 & - & $\begin{array}{l}\text { Garibay et al. } \\
\text { unpublished }\end{array}$ \\
\hline H. russula & 4433 & Canada, Quebec & KM248883 & - & $\begin{array}{l}\text { Berube et al. } \\
\text { unpublished }\end{array}$ \\
\hline
\end{tabular}




\begin{tabular}{|c|c|c|c|c|c|}
\hline Taxon & Voucher & Locality & $\begin{array}{l}\text { GenBank } \\
\text { Accession No. (ITS) }\end{array}$ & $\begin{array}{l}\text { GenBank Accession } \\
\text { No. (LSU) }\end{array}$ & References \\
\hline H. russula & NIFoS 1987 & South Korea, - & KX814449 & - & Wang et al. 2016 \\
\hline H. russula & NIFoS 2003 & South Korea, - & KX814450 & - & Wang et al. 2016 \\
\hline H. russula & MB344 & USA, Arkansas & KX358034 & - & $\begin{array}{l}\text { Stephenson et al. } \\
2017\end{array}$ \\
\hline H. russula & EMB 141/86 & Italy, - & MF399419 & - & $\begin{array}{l}\text { Peintner et al. } \\
\text { unpublished }\end{array}$ \\
\hline H. russula & EMB 710/90 & Italy, - & MF399423 & - & $\begin{array}{l}\text { Peintner et al. } \\
\text { unpublished }\end{array}$ \\
\hline H. russula & IB19630793 & $\begin{array}{l}\text { Switzerland, } \\
\text { Lucerne }\end{array}$ & MF399427 & - & $\begin{array}{l}\text { Peintner et al. } \\
\text { unpublished }\end{array}$ \\
\hline H. russula & IB19710232 & Switzerland, Bern & MF399432 & - & $\begin{array}{l}\text { Peintner et al. } \\
\text { unpublished }\end{array}$ \\
\hline H. russula & IB19730073 & Switzerland, Bern & MF399433 & - & $\begin{array}{l}\text { Peintner et al. } \\
\text { unpublished }\end{array}$ \\
\hline H. russula & IB19740604 & France, Provence & MF399434 & - & $\begin{array}{l}\text { Peintner et al. } \\
\text { unpublished }\end{array}$ \\
\hline H. russula & $\begin{array}{l}\text { iNaturalist } \\
31828832\end{array}$ & USA, Arizona & MN498103 & - & $\begin{array}{l}\text { Clements and Tighe } \\
\text { unpublished }\end{array}$ \\
\hline H. cf. russula & JLF 7925 & USA, Arizona & MT101865 & - & Frank unpublished \\
\hline H. russula & IB 19740604 & France, - & MT158400 & - & $\begin{array}{l}\text { Papetti et al. } \\
\text { unpublished }\end{array}$ \\
\hline H. russula & EMB 14186 & Italy, - & MT158401 & - & $\begin{array}{l}\text { Papetti et al. } \\
\text { unpublished }\end{array}$ \\
\hline H. russula & EMB 71090 & Italy, - & MT158402 & - & $\begin{array}{l}\text { Papetti et al. } \\
\text { unpublished }\end{array}$ \\
\hline H. russula & IB19630793 & Switzerland, - & MT158403 & - & $\begin{array}{l}\text { Papetti et al. } \\
\text { unpublished }\end{array}$ \\
\hline $\begin{array}{l}H . \\
\text { russuliformis }\end{array}$ & MICH 10939 & USA, Florida & MF399455 & - & $\begin{array}{l}\text { Peintner et al. } \\
\text { unpublished }\end{array}$ \\
\hline H. sordidus & AHSmith 91580 & USA, Wisconsin & EF395373 & - & $\begin{array}{l}\text { Jacobsson and } \\
\text { Larsson } 2007\end{array}$ \\
\hline H. yunnanensis & $\begin{array}{l}\text { MHKMU S.D. } \\
\text { Yang } 12-1\end{array}$ & China, Yunnan & - & MW290262* & This study \\
\hline H. yunnanensis & $\begin{array}{l}\text { MHKMU S.D. } \\
\text { Yang } 12-2\end{array}$ & China, Yunnan & - & MW290263* & This study \\
\hline H. yunnanensis & $\begin{array}{l}\text { MHKMU J. Zhao } \\
52\end{array}$ & China, Yunnan & MW290207* & MW290264* & This study \\
\hline H. yunnanensis & HKAS 56982 & China, Yunnan & MW290208* & MW290265* & This study \\
\hline H. yunnanensis & HKAS 50442 & China, Yunnan & MW290209* & - & This study \\
\hline H. yunnanensis & HKAS 72912 & China, Yunnan & MW290210* & MW290266* & This study \\
\hline H. yunnanensis & $\begin{array}{l}\text { MHKMU L.P. } \\
\text { Tang } 2751\end{array}$ & China, Yunnan & - & MW290267* & This study \\
\hline H. yunnanensis & $\begin{array}{l}\text { MHKMU L.P. } \\
\text { Tang } 2772\end{array}$ & China, Yunnan & MW290211* & MW290268* & This study \\
\hline
\end{tabular}




\begin{tabular}{|c|c|c|c|c|c|}
\hline Taxon & Voucher & Locality & $\begin{array}{l}\text { GenBank } \\
\text { Accession No. (ITS) }\end{array}$ & $\begin{array}{l}\text { GenBank Accession } \\
\text { No. (LSU) }\end{array}$ & References \\
\hline H. yunnanensis & $\begin{array}{l}\text { MHKMU L.P. } \\
\text { Tang } 2773\end{array}$ & China, Yunnan & MW290212* & MW290269* & This study \\
\hline H. yunnanensis & $\begin{array}{l}\text { MHKMU H.Y. } \\
\text { Huang } 313\end{array}$ & China, Yunnan & - & MW290270* & This study \\
\hline H. yunnanensis & $\begin{array}{l}\text { MHKMU H.Y. } \\
\text { Huang } 316\end{array}$ & China, Yunnan & - & MW290271* & This study \\
\hline H. yunnanensis & $\begin{array}{l}\text { MHKMU H.Y. } \\
\text { Huang } 321\end{array}$ & China, Yunnan & MW290213* & MW290272* & This study \\
\hline H. yunnanensis & $\begin{array}{l}\text { MHKMU H.Y. } \\
\text { Huang } 322\end{array}$ & China, Yunnan & MW290214* & MW290273* & This study \\
\hline \multicolumn{6}{|l|}{ (Holotype) } \\
\hline H. yunnanensis & $\begin{array}{l}\text { MHKMU H.Y. } \\
\text { Huang } 334\end{array}$ & China, Yunnan & - & MW290274* & This study \\
\hline H. yunnanensis & $\begin{array}{l}\text { MHKMU H.Y. } \\
\text { Huang } 336\end{array}$ & China, Yunnan & - & MW290275* & This study \\
\hline H. yunnanensis & 072607 & China, Yunnan & MW290215* & MW290276* & This study \\
\hline H. yunnanensis & $\begin{array}{l}\text { MHKMU M. Mu } \\
439\end{array}$ & China, Yunnan & - & MW290277* & This study \\
\hline H. yunnanensis & $\begin{array}{l}\text { MHKMU H.Y. } \\
\text { Huang } 969\end{array}$ & China, Yunnan & - & MW290278* & This study \\
\hline H. yunnanensis & $\begin{array}{l}\text { MHKMU H.Y. } \\
\text { Huang } 970\end{array}$ & China, Yunnan & - & MW290279* & This study \\
\hline H. yunnanensis & $\begin{array}{l}\text { MHKMU H.Y. } \\
\text { Huang } 971\end{array}$ & China, Yunnan & - & MW290280* & This study \\
\hline
\end{tabular}

\section{Results}

Phylogenetic analysis

One hundred and forty ITS and LSU sequences were newly generated for the $H$. russula complex in this study. DNA sequences were edited and aligned. The alignment length is 585 characters for the ITS dataset, 888 characters for the LSU dataset and 1471 for the concatenated dataset. Sequences of the $H$. russula complex were selected as the ingroup, $H$. sordidus Peck and $H$. penarioides Jacobsson \& E. Larss. in subsection Clitocyboides served as outgroups, based on the previous study (Huang et al. 2018). The alignment is available at TreeBASE (Accession 27296 http://purl.org/phylo/treebase/phylows/study/TB2:S27296). All sequences acquired from this study are listed in Table 1.

The phylogenetic trees from BI and RAxML were almost identical, while statistical support showed slight differences. The ITS and concatenated trees were almost identical. Twelve phylogenetic species were recovered under the name of "H. russula" from Asia, Europe, North America and South America (Figs. 1-4). European "H. russula" formed three groups. Sequences of "H. russula" from North America represented five phylogenetic species. The Belize sequence of " $H$. russula" represented the South American group forming a single branch, which is the basal group of the H. russula species complex in the ITS trees (Fig. 1). The Chinese collections respectively formed five monophyletic clades with strong support, corresponding to five taxa, three new $(H$. orientalis, $H$. qinggangjun and $H$. yunnanensis) and two known taxa (H. deliciosus and H. parvirussula). These collections of " $H$. russula" from the same continent did not cluster together, although some may have close relationships. For example, $H$. deliciosus exhibited a sister 
relationship with $H$. qinggangjun with strong support in the ITS and concatenated trees, but appeared to be sister to $H$. yunnanensis in the LSU tree. Hygrophorus parvirussula and H. russula were sister species in the ITS, LSU and concatenated trees. Hygrophorus orientalis had a close relationship to " $H$. russula" from Europe, probably as its Europe vicariant; the relationships cannot be resolved according to the present data and needs further research.

Chemical reactions studies

$\mathrm{FeSO}_{4}, \mathrm{NH}_{4} \mathrm{OH}, \mathrm{KOH}$ and Melzer's Reagent were applied to test possible colour changes, which help to delimit sections or distinguish some species in Hygrophorus (Helser and Smith 1963; Larsson and Jacobsson 2004; Moreau et al. 2018). In this study, we used seven reagents, based on the previous study (Huang et al. 2018). All species in the $H$. russula complex from China showed a negative reaction to $\mathrm{EtOH}, \mathrm{FeCl}_{3}, \mathrm{FeSO}_{4}, \mathrm{KOH}, \mathrm{NH}_{4} \mathrm{OH}$ and Melzer's Reagent, with the pileus turning pinkish in $\mathrm{C}_{6} \mathrm{H}_{5} \mathrm{OH}$.

\section{Taxonomy}

Hygrophorus deliciosus C.Q. Wang \& T.H. Li, Phytotaxa 449: 232-242, 2020 (Figs. 5, 6a, 7a, 8a, 9a, 10a)

The following description is mainly taken from Wang and $\mathrm{Li}$ (2020), combined with our field notes including macro-morphology, growth habit, distribution, host plants and examination.

\section{Description}

Basidiomata sparsely scattered to gregarious on soil, medium-sized, fleshy, rather fragile. Pileus 5-14 cm diam., rounded-conical to convex at first, expanding to plane at maturity; dirty white, flesh pink (10A3) to reddish-brown (10C7), covered with pale reddish-brown or reddish-purple (10C7-8) scales. Context white to pinkish (10A2), up to $2.4 \mathrm{~cm}$ thick. Lamellae adnate to decurrent, subdistant, 6075 pieces of complete lamellae/cap, $0.5-1 \mathrm{~cm}$ wide, white to flesh pink (10A2-3), the surface often covered by reddish-purple (10C78) spots, short gills or lamellulae numerous and narrowed. Stipe 7-12 cm long, 1-2.2 cm diam., central, cylindrical, equal, white, yellowish-white, pinkish (10A2), with red (10A7) to brownish-red (10D7) scales. Flesh often pinkish (10A2). Basal mycelium white. Odour not distinctive. Taste mild.

Basidiospores [80/6/6] 6.44-8 (-9) $\times 4.6-6 \mu \mathrm{m}, \mathrm{Q}=1.25-1.6, \mathrm{Q}_{\mathrm{m}}=1.42 \pm 0.12$, broad ellipsoid to ellipsoid, smooth under a light microscope and SEM, thin-walled, hyaline, with a distinct hilar appendix, yellowish in Melzer's Reagent. Basidia 45-55 × 4-7 $\mu \mathrm{m}$, mostly 4-spored, occasionally 2-spored, clavate, slender, thin-walled; sterigmata 6-10 $\mu \mathrm{m}$ in length. Cheilocystidia 29-43 $\times 3-4 \mu \mathrm{m}$, rare, scattered, subfusiform, narrowly clavate, spathulate, subcylindrical, flexuous, thin-walled, colourless. Pleurocystidia 32-50 × 3-6 $\mu \mathrm{m}$, abundant, scattered, subfusiform, narrowly clavate, spathulate, flexuous, thin-walled, hyaline. Lamellar trama divergent, composed of short elements and long hyphae, short elements 10-25 × 3-4 $\mu \mathrm{m}$, next to hymenium, cylindrical, long ellipsoid, pear-shaped or irregularly-shaped, colourless and hyaline; long hyphae 3-15 $\mu \mathrm{m}$ broad, long ellipsoid, clavate or irregularly-shaped, colourless and hyaline. Pileipellis an ixotrichoderm, consisting of narrow hyphae 2-5 $\mu \mathrm{m}$ diam. in gluten, loosely interwoven, branched or nonbranched, thin-walled. Pileal trama made up of hyphae 6-20 $\mu \mathrm{m}$ diam., thin-walled. Stipitipellis a cutis, composed of hyphae 3-5 $\mu \mathrm{m}$ diam., thin-walled, mostly arranged in parallel. Stipititrama made up of hyphae 6-18(-30) $\mu \mathrm{m}$ diam., arranged in parallel, thin-walled. Mycelial hyphae 2-4 $\mu \mathrm{m}$ broad, smooth under a light microscope, mostly smooth and occasionally covered with a massive nippleshaped protuberance under SEM. Clamp connections present in all tissues.

\section{Known distribution}

South-western China, the subalpine to the alpine belt of Sichuan, Tibet and Yunnan.

\section{Habit and habitat}

Scattered or gregarious in broad-leaved forests, mainly Fagaceae (Quercus aquifolioides), elev. 1990-3700 m; in summer (JulySeptember).

Additional materials examined: CHINA. Sichuan Province: Litang Prefecture, Junba Town, $30^{\circ} 18.70^{\prime} \mathrm{N}, 100^{\circ} 17.73^{\prime} \mathrm{E}$, elev. $3630-3675 \mathrm{~m}$, 26 August 2006, Z.W. Ge 1414 (HKAS 51000); Muli Prefecture, Liziping Town, elev. 3400-3700 m, 1 August 2012, T. Guo 554 (HKAS 76246). Tibet Autonomous Region: Linzhi Prefecture, Lulang Town, elev. 3325 m, 11 August 2013, T.Z. Wei 3592 (HMAS 253198); Milin Prefecture, elev. 2990 m, 12 August 2013, T.Z. Wei \& T.Z. Li \& X.Y. Liu \& J.Y. Zhuang 3694 (HMAS 253249); Milin Prefecture, elev. 2990 
m, 12 August 2013, T.Z. Wei \& T.Z. Li \& X.Y. Liu \& J.Y. Zhuang 3740 (HMAS 253233). Yunnan Province: Chuxiong City, Nanhua Wild Mushrooms Market, elev. unknown, 5 August 2020, H.Y. Huang 725 (MHKMU H.Y. Huang 725); Jianchuan Prefecture, Diannan Town, elev. unknown, 10 August 2010, J. Zhang 5 (HKAS 61315); Jianchuan Prefecture, Shaxi Town, elev. 3018 m, 6 October 2020, H.Y. Huang 1006 (MHKMU H.Y. Huang 1006), H.Y. Huang 1008 (MHKMU H.Y. Huang 1008); Jianchuan Prefecture, Shibao Mountain, elev. about $2500 \mathrm{~m}, 11$ August 2010, X.Y. Zhou 14 (HKAS 61276); the same location, 26²3.73'N, 9950.41'E, elev. $2540 \mathrm{~m}, 19$ August 2014, S.D. Yang 43 (MHKMU S.D. Yang 43); Kunming City, the Park of Wild Duck Lake, elev. 1990 m, 17 September 2008, Z.L. Yang 5214 (HKAS 54510); Lanping Prefecture, elev. 2700 m, 14 August 2011, J.Y. Hao 515 (HKAS 71624); Lijiang City, Gucheng Area, elev. 2600 m, 18 August 2010, Q. Zhao 949 (HKAS 69670); Lijiang City, Taian Town, elev. about 3200 m, 19 August 2020, H. Y. Huang 806 (MHKMU H.Y. Huang 806), H.Y. Huang 807 (MHKMU H.Y. Huang 807); Yulong Prefecture, Lijiang Observatory, elev. about 3100 m, 20 July 2008 , Q. Zhao 852 (HKAS 55053); Yulong Prefecture, Yulong Snow Mountains, elev. 2940 m, 24 July 2008, L.P. Tang 472 (HKAS 54703).

\section{Comments}

Hygrophorus deliciosus is quite common in SW China as a wild commercial fungus known from the local name "Qinggangjun" or "Mitangjun". "Mitang" is a kind of soup made from rice. "Mitangjun" means that this mushroom soup is thick and looks like "Mitang". This species grows scattered to gregarious at varied elevations from 1900 to $3700 \mathrm{~m}$. It is distinguished by its medium-sized basidiomata, thick context (up to $2.4 \mathrm{~cm}$ ), broad ellipsoid basidiospores and probably associated with Quercus aquifolioides.

This species is most likely to be confused with $H$. qinggangjun; both are sold as edible mushrooms in Yunnan Province markets and has been identified from the samples of Nanhua Wild Mushrooms Market. These two species have a very weak or mild taste when fresh and a little bitter after cooking. Hygrophorus qinggangjun has a narrow distribution (Yunnan Province) and elevation (2000-2780 $\mathrm{m})$, wavy and uplifted margin, thin context $(0.4-0.9 \mathrm{~cm})$, broad basidia $(43-49 \times 6-9 \mu \mathrm{m})$ and varied basidiospores (broad ellipsoid, ellipsoid and oblong). This taxon prefers to grow in a solitary manner or scattered in mixed forests, probably associated with Quercus serrata.

According to our phylogenetic analyses, $H$. deliciosus exhibits a sister relationship with $H$. qinggangjun with strong support in the ITS and concatenated trees, but appears to be sister to H. yunnanensis in the LSU tree (Figs. 1-3). However, H. yunnanensis has small basidiomata (pileus 5-15 cm), thin context $(0.3-0.7 \mathrm{~cm}$ ), narrow basidiospores [(7-) 7.5-9.5 $\times 4-5 \mu \mathrm{m}]$, is so far restricted to Yunnan Province and prefers to grow alone or sparsely scattered in low elevations $(2100-2600 \mathrm{~m})$. This taxon is probably associated with Lyonia ovalifolia and Ternstroemia gymnanthera.

Hygrophorus orientalis H.Y. Huang \& L.P. Tang, sp. nov. (Figs. 6b, 7b, 8b, 9b, 10b, 11)

MycoBank: MB 838040.

\section{Diagnosis}

Hygrophorus orientalis is different from other species of the $H$. russula complex in having large basidiomata, dense lamellae, small basidiospores and an extensive distribution.

\section{Etymology}

Latin "orientalis" means the species is widely distributed in East Asia.

Holotype: CHINA. Hubei Province: Shennongjia Forestry District, Muyu Town, in forests dominated by Fagaceae, $31^{\circ} 40.83^{\prime} \mathrm{N}$, 110²6.45'E, elev. 1900 m, 18 July 2012, Q. Cai 852 (HKAS 75586).

\section{Description}

Basidiomata solitary to gregarious on soil, large. Pileus $9-25 \mathrm{~cm}$ diam., often with a depressed centre and an in-rolled margin; pink (10A2-3), purplish-pink (14A4) to rose red (14A8), darker at the centre, covered with reddish-brown (10C7-8) scales. Context white (A1), up to $3 \mathrm{~cm}$ thick. Lamellae adnate to slightly decurrent, crowded, $120-145$ pieces of complete lamellae/cap, $0.5-1 \mathrm{~cm}$ wide, white to yellowish (1A2), rather fragile, concolorous (14A4) with the pileus when damaged, some gills branched. Stipe 7-15 cm long, $2.5-5$ $\mathrm{cm}$ diam., solid, fibrillose, central to slightly eccentric, cylindrical, equal, more or less concolorous (10A2-3) with the pileus, covered with reddish-brown (10C7-8) scales, surface cracking and upward curved with age; flesh pink (10A2-3); basal mycelium white. Odour and taste not recorded. 
Basidiospores [80/5/5] 5.5-7 (-8) × 3.5-4.8 (-5) $\mu \mathrm{m}, \mathrm{Q}=(1.3-)$ 1.33-1.79, $\mathrm{Q}_{\mathrm{m}}=1.57 \pm 0.15$, ellipsoid, smooth under a light microscope and SEM, thin-walled, hyaline, with a distinct hilar appendix, yellowish in Melzer's Reagent. Basidia 30-40 × 4-7 $\mu \mathrm{m}, 4-$ spored, clavate, thin-walled; sterigmata 4-7 $\mu \mathrm{m}$ in length. Cheilocystidia 30-40 $\times 3-5 \mu \mathrm{m}$, rare, scattered, subfusiform, narrowly clavate, spathulate, subcylindrical, flexuous, thin-walled, colourless. Pleurocystidia $28-35 \times 3-5 \mu \mathrm{m}$, rare, scattered, subfusiform, spathulate, flexuous, thin-walled, hyaline. Lamellar trama divergent, composed of short elements and long hyphae, short elements 5$15 \times 4-7 \mu \mathrm{m}$, next to hymenium, subcylindrical, broadly ellipsoid, pear-shaped or irregularly-shaped, colourless and hyaline; long hyphae 4-18 $\mu \mathrm{m}$ broad, long ellipsoid, clavate or irregularly-shaped, colourless and hyaline. Pileipellis an ixotrichoderm, consisting of narrow hyphae (2.5-4.5 $\mu \mathrm{m}$ diam.) in gluten, loosely interwoven, branched or non-branched, thin-walled. Pileal trama made up of hyphae 4-22 $\mu \mathrm{m}$ diam., thin-walled. Stipitipellis a cutis, composed of hyphae 3-6 $\mu \mathrm{m}$ diam., thin-walled, mostly arranged in parallel. Stipititrama made up of hyphae 6-20 $\mu \mathrm{m}$ diam., arranged in parallel, thin-walled. Mycelial hyphae 2-5 $\mu \mathrm{m}$ broad, smooth under a light microscope, mostly smooth and occasionally covered with a massive nipple-shaped protuberance under SEM. Clamp connections present in all tissues.

Known distribution: East Asia: including China, Japan (GenBank accession KF291216), South Korea (GenBank accession KX814449814450).

\section{Habit and habitat}

Scattered to gregarious, at times in arcs or fairy rings, in broad-leaved forests, mainly Fagaceae, probably associated with Cyclobalanopsis sp. or Quercus mongolica, elev. 750-2340 m; in summer (July-September).

Additional materials examined: CHINA. Inner Mongolia: Ningcheng Prefecture, Heilihe National Nature Reserve, in broad-leaved forests, mainly Quercus mongolica, mixed with Corylus heterophylla and Corylus mandshurica, elev. ca. 770-1840 m, 20 August 2019, T. Z. Liu 19-520 (CFSZ 20884). Jilin Province: Antu Prefecture, the Changbai Mountain Scenic Area, in broad-leaved forests, mainly Fagaceae, elev. 750 m, 7 August 2010, X.F. Shi 450 (HKAS 63417, HKAS 71845); the same location, in broad-leaved forests, mainly Fagaceae (Q. mongolica), mixed with a few Betulaceae (e.g. Betula platyphylla and C. heterophylla), Pinaceae (Pinus koraiensis), $42^{\circ} 24.27^{\prime} \mathrm{N}$, $128^{\circ} 6.10^{\prime}$ E, elev. 760 m, 2 September 2019, H.Y. Huang 472 (MHKMU H.Y. Huang 472). Shanxi Province: Mei Prefecture, Yingtou Town, in broad-leaved forests, mainly Cyclobalanopsis sp. and Fagaceae, elev. 1280 m, 4 September 2010, X.F. Shi 659 (HKAS 71851). Yunnan Province: Yongping Prefecture, Longmen Town, elev. 2340 m, 1 August 2009, Q. Cai 74 (HKAS 58741).

\section{Comments}

Hygrophorus orientalis can be recognised from other species of the H. russula complex by its large basidiomata, dense lamellae, small basidiospores and scattered to gregarious (at times in arcs or fairy rings) growth habit, probably associated with Cyclobalanopsis sp. or Quercus mongolica. This taxon has a wide distribution in East Asia (including China, Japan and South Korea), usually occurring below elev. $2400 \mathrm{~m}$. It is known as an edible mushroom in NE China, where locals prefer it raw rather than cooked.

Phylogenetically, this species is related to " $H$. russula" from Europe, probably as its Europe vicariant; the sister relationship of $H$. orientalis cannot be resolved according to the present data and needs further research.

Hygrophorus qinggangjun H.Y. Huang \& L.P. Tang, sp. nov. (Figs. 6d, 7c, 8c, 9c, 10c, 12)

MycoBank: MB 838039.

\section{Diagnosis}

Hygrophorus qinggangjun is different from other species of the H. russula complex in its medium-sized basidiomata, uplifted and wavy margin, thinner context, variable basidiospores (broad ellipsoid, ellipsoid and oblong) and so far, only being known from Yunnan.

\section{Etymology}

Latin "qinggangjun" means the host plant of this mushroom, "qinggang" trees referring to oak trees in SW China.

Holotype: CHINA. Yunnan Province: Jianchuan Prefecture, Shibao Mountain, in a mixed forest with Ericaceae, Fagaceae and a few Pinus yunnanensis, $26^{\circ} 23.73^{\prime} \mathrm{N}, 9^{\circ} 50.41^{\prime} \mathrm{E}$, elev. $2500 \mathrm{~m}$, 18 August 2014, L.P. Tang 1683 (MHKMU L.P. Tang 1683). 


\section{Description}

Basidiomata solitary to sparsely scattered on soil, medium-sized to large, fleshy, rather fragile. Pileus 8-14 cm diam., convex with an incurved margin when young, becoming plane with a depressed centre, margin often wavy and uplifted in age, reddish-white to pink (10A2-3), pale reddish-purple (12A5), with reddish-brown (10C7-8) scales, viscid to slimy when wet. Context white to pink-white (10A2), becoming darker (10A3) on exposure, $0.4-0.9 \mathrm{~cm}$ thick. Lamellae decurrent, subdistant, $60-80$ pieces of complete lamellae/cap, 0.9-1.2 cm wide, pinkish (10A2-3) to reddish (10A5), short gills or lamellulae narrowed, rather fragile. Stipe 7-10 cm long, 1-1.7 cm diam., central to slightly eccentric, cylindrical, equal, surface pinkish (10A2-3) to reddish-purple (14A2), with dark reddish-violet (10C7-8) scales. Flesh firm, pinkish-white to pinkish (10A2), pale reddish-purple (10A3), becoming darker when cut or on exposure. Basal mycelium white. Odour not distinctive. Taste very weak.

Basidiospores [90/4/4] 6.44-9 (-9.5) × (4-) 4.4-6 (-6.5) $\mu \mathrm{m}, \mathrm{Q}=(1.15-)$ 1.24-1.64 (-1.89), $\mathrm{Q}_{\mathrm{m}}=1.46 \pm 0.14$, broad ellipsoid, ellipsoid, oblong, smooth under a light microscope and SEM, thin-walled, hyaline, with a distinct hilar appendix, yellowish in Melzer's Reagent. Basidia 43-49 × 6-9 $\mu \mathrm{m}$, mostly 4-spored, clavate, thin-walled; sterigmata 5-10 $\mu \mathrm{m}$ in length. Cheilocystidia 25-40 $\times 3-7$ $\mu \mathrm{m}$, rare, scattered, subfusiform, narrowly clavate, spathulate, irregularly-shaped, flexuous, thin-walled, colourless. Pleurocystidia 25$40 \times 4-6 \mu \mathrm{m}$, scattered, narrowly clavate, spathulate, flexuous, thin-walled, hyaline. Lamellar trama divergent, composed of short elements and long hyphae, short elements 6-20 $\times 3-5 \mu \mathrm{m}$, next to hymenium, cylindrical, long ellipsoid, pear-shaped or irregularlyshaped, colourless and hyaline; long hyphae 5-20 (-28) $\mu \mathrm{m}$ broad, long ellipsoid, clavate or irregularly-shaped, colourless and hyaline. Pileipellis an ixotrichoderm, consisting of narrow hyphae (2-6 $\mu \mathrm{m}$ diam.) in gluten, loosely interwoven, branched or non-branched, thinwalled. Pileal trama made up of hyphae 7-20 $\mu \mathrm{m}$ diam., thin-walled. Stipitipellis a cutis, composed of hyphae 3-6 $\mu \mathrm{m}$ diam., thinwalled, mostly arranged in parallel. Stipititrama made up of hyphae 6-18 $\mu \mathrm{m}$ diam., arranged in parallel, thin-walled. Mycelial hyphae 2-5 $\mu \mathrm{m}$ broad, smooth under a light microscope, mostly smooth and occasionally covered with a massive nipple-shaped protuberance under SEM. Clamp connections present in all tissues.

\section{Known distribution}

Yunnan Province.

\section{Habit and habitat}

Solitary or scattered in mixed forests, mainly including Ericaceae and Fagaceae, probably associated with Quercus serrata; elev. 2000$2780 \mathrm{~m}$; in late summer and autumn (August-October).

Additional materials examined: CHINA. Yunnan Province: Chuxiong City, Nanhua Wild Mushrooms Market, elev. unknown, 5 August 2020, H.Y. Huang 724 (MHKMU H.Y. Huang 724); Jianchuan Prefecture, Shibao Mountain, in a mixed forest with Ericaceae, Fagaceae and Pinaceae, $26^{\circ} 23.73^{\prime} \mathrm{N}, 99^{\circ} 50.41^{\prime} \mathrm{E}$, elev. $2500 \mathrm{~m}, 18$ August 2014, S.D. Yang 20 (MHKMU S.D. Yang 20); the same location, occurred under Quercus sp., probably Q. serrata, $26^{\circ} 23.78^{\prime} \mathrm{N}, 99^{\circ} 50.32^{\prime} \mathrm{E}$, elev. $2530 \mathrm{~m}, 13$ September 2019, M. Mu 436 (MHKMU M. Mu 436); the same location, in a mixed forest with Ericaceae, Quercus sp. and a few Pinus yunnanensis, $26^{\circ} 23.67^{\prime} \mathrm{N}, 99^{\circ} 50.18^{\prime} \mathrm{E}$, elev. $2520 \mathrm{~m}, 14$ September 2019, M. Mu 464 (MHKMU M. Mu 464); Kunming City, Shuanglong Town, elev. about 2000 m, 17 September 2008, X.H. Du 39 (HKAS 55496); Lijiang City, Qihe Town, elev. 2780 m, 19 August 2010, X.T. Zhu 221 (HKAS 68397); Weixi Prefecture, Qizong Town, elev. unknown, 19 September 2010, X.H. Wang 44 (HKAS 60530); Weixi Prefecture, Tacheng Town, elev. unknown, 20 September 2010, X.H. Wang 121 (HKAS 60481); the same location, elev. unknown, 15 October 2011, X.H. Wang 127 (HKAS 72665); location unknown, elev. unknown, 1 August 2009, Q. Zhao 447.

\section{Comments}

In SW China, $H$. qinggangjun is a wild edible mushroom, also known locally as "Mitangjun" or "Qinggangjun". Thus, there are at least two species under this common name based on our research, viz. H. deliciosus and $H$. qinggangjun. Currently, H. qinggangjun is known only from Yunnan Province, occurring at high elevation regions $(2000-2780 \mathrm{~m})$. This mushroom is distinguished by its medium-sized basidiomata, wavy and uplifted margin, thin context $(0.4-0.9 \mathrm{~cm})$, broad basidia $(43-49 \times 6-9 \mu \mathrm{m})$ and varied basidiospores (broad ellipsoid, ellipsoid and oblong) and is solitary or scattered in mixed forests, probably in association with Quercus serrata.

The morphological and phylogenetic analyses (except the LSU tree) show that $H$. qinggangjun is closely related to $H$. deliciosus, the comparison between $H$. deliciosus and $H$. qinggangjun can be found in our treatment of $H$. deliciosus. 
Hygrophorus russula (Schaeff. ex Fr.) Kauffman, Publications Michigan Geology Biology Survey, Biology Series 5 26: 185, 1918

(Fig. 6e)

The following description is mainly taken from Bas et al. (1990) and Candusso (1997), combined with our field notes including macromorphology, growth habit, distribution, host plants and examination.

\section{Description}

Basidiomata solitary to sub-gregarious on soil, medium-sized, fleshy, rather fragile. Pileus 4-10 $(-15) \mathrm{cm}$ diam., hemispherical, convex, applanate, firstly almost white to pale pink with scattered pink to wine-red spots or appressed, fibrillose scales, gradually darker, becoming pinkish-red to wine-red at the centre, finally dark purplish-red, with small to larger concolorous spots elsewhere, surface dry to slight viscid. Context white, becoming pale pink to pinkish-purple when damaged, up to $2.5 \mathrm{~cm}$ thick. Lamellae adnate to shortdecurrent, rather crowded to subdistant, 70-150 pieces of complete lamellae/cap, narrow, up to $0.5 \mathrm{~cm}$ wide, at first white to very pale pink, then spotted wine-red, brown-red or purplish-red, finally entirely dark reddish. Stipe 6-10 $(-15) \mathrm{cm}$ long, $0.8-2.5(-4) \mathrm{cm}$ diam., cylindrical, solid, dry, equal or slightly tapering towards base, white with some wine-red to purplish-red spots to almost completely brownish-purple. Odour absent to rather weakly unpleasant, sweetish. Taste mild.

Basidiospores [20/2/2] 8-10 $\times 5-6.5 \mu \mathrm{m}, \mathrm{Q}=1.33-1.72, \mathrm{Q}_{\mathrm{m}}=1.55 \pm 0.12$, broad ellipsoid to ellipsoid, smooth under a light microscope, thin-walled, hyaline, with a distinct hilar appendix, yellowish in Melzer's Reagent. Basidia 55-68 $(-80) \times 7-9(-10) \mu \mathrm{m}, 4-$ spored, clavate, slender, thin-walled; sterigmata 4-7 $\mu \mathrm{m}$ in length. Cheilocystidia 35-50 $\times 3-5 \mu \mathrm{m}$, rare, scattered, irregularly-shaped, narrowly clavate, flexuous, thin-walled, colourless. Pleurocystidia 40-55 $\times 3-9 \mu \mathrm{m}$, scattered, irregularly-shaped, narrowly clavate, flexuous, thin-walled, hyaline. Lamellar trama divergent, composed of short elements and long hyphae, short elements 15-26 $\times 3-6$ $\mu \mathrm{m}$, next to hymenium, cylindrical, long ellipsoid, pear-shaped or irregularly-shaped, colourless and hyaline; long hyphae 3-10 (-25) $\mu \mathrm{m}$ broad, up to $70 \mu \mathrm{m}$ long, long ellipsoid, clavate or irregularly-shaped, colourless and hyaline. Pileipellis an ixotrichoderm, consisting of narrow hyphae (2-4 $\mu \mathrm{m}$ diam.) in gluten, loosely interwoven, branched or non-branched, thin-walled. Pileal trama made up of hyphae 4-25 $\mu \mathrm{m}$ diam., thin-walled. Stipitipellis a cutis, composed of hyphae $2.5-4.5 \mu \mathrm{m}$ diam., thin-walled, mostly arranged in parallel. Clamp connections present in all tissues.

\section{Known distribution}

Europe.

\section{Habit and habitat}

Solitary to sub-gregarious in mixed forests, associated with Quercus spp., mainly Q. ilex, elev. below $1100 \mathrm{~m}$; in autumn to winter (September-December).

\section{Additional materials examined}

SPAIN. Huesca city, Javierregay, on humus under oak and Quercus sp., elev. 680 m, 5 December 2009, A. González \& F. Prieto s. n. (AH 37145); Madrid City, Torrelodones, in mixed forests, including Pinus pinaster and Quercus ilex subsp. ballota., elev. 845 m, 7 December 2000, F. Prieto s. n. (AH 19676); the same location, in mixed forests, including P. pinaster and Q. ilex subsp. ballota., elev. $845 \mathrm{~m}, 1$ December 2001, F. Prieto s. n. (AH 19677).

\section{Comments}

Hygrophorus russula was originally described from Germany as Agaricus russula Schaeff. in 1774 (Schaeffer 1774, Fries 1821), but with few macroscopic details and without microscopic details in the original description. Subsequently, it was placed in the genus Tricholoma in 1878 (Gillet 1878). It was then placed in the genus Hygrophorus, i.e. H. russula (Schaeff. ex Fr.) Kauffman in 1918 (Kauffman 1918). Kauffman CH firstly described this mushroom in detail, based on American collections. Hygrophorus russula was long assumed to have a widespread distribution and has been reported from several countries and continents (Hesler and Smith 1963; Hongo 1982; Bas et al. 1990; Candusso 1997; Chen and Li 2013; Siegel and Schwarz 2016). Spanish material in this study matches the description based on European collections (Bas et al. 1990; Candusso 1997). According to those references and our study, European $H$. russula is distinguished by its solitary to sub-gregarious habit at low elevations (below $1100 \mathrm{~m}$ ), medium-sized baisidiomata, narrow 
lamellae and large basidiospores, occurring under Quercus spp., principally Q. ilex, more rarely Q. cerris, Q. pubescens, Q. pyrenaica and $Q$. suber, mainly on basic soil. We confirm that $H$. russula is a strictly European species, based on this study.

The phylogenetic analyses show that this species is a sister species of $H$. parvirussula. However, H. parvirussula differs from $H$. russula by its solitary to sparsely scattered habit at high elevations $(2500-3300 \mathrm{~m})$, associated with Pieris formosa and Rhododendron concinnum, smaller basidiomata and narrower basidiospores $\left(6.9-9.0 \times 4.6-6.9 \mu \mathrm{m}, \mathrm{Q}=1.13-1.83, \mathrm{Q}_{\mathrm{m}}=1.48 \pm 0.23\right)$.

Hygrophorus yunnanensis H.Y. Huang \& L.P. Tang, sp. nov. (Figs. 6f, 7d, 8d, 9d, 10d, 13)

MycoBank: MB 838041.

\section{Diagnosis}

Hygrophorus yunnanensis is different from other species of the $\mathrm{H}$. russula complex by its small basidiomata, thin context, narrow basidiospores and, so far, is only known from Yunnan.

\section{Etymology}

Latin "yunnanensis" means the species from Yunnan Province.

Holotype: CHINA. Yunnan Province: Qujing City, Shizong Town, in broad-leaved forests mainly dominated by Lyonia ovalifolia, mixed

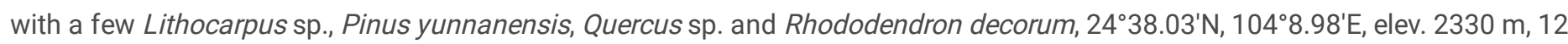
August 2019, H.Y. Huang 322 (MHKMU H.Y. Huang 322).

\section{Description}

Basidiomata solitary to sparsely scattered on soil, small to medium-sized, firm, fleshy. Pileus $4-8 \mathrm{~cm}$ diam., convex to hemispherical with an in-rolled margin at first, expanding to plane at maturity; pale reddish-purple (12A5), dark red to reddish-brown (10C7-8), with a dark centre covered with scales. Context pinkish-white (10A2), becoming darker (10A3) on exposure, 0.3-0.7 cm thick. Lamellae adnate to slightly decurrent, subdistant, 70-95 pieces of complete lamellae/cap, 0.3-0.8 cm wide, pale pinkish (10A2), pinkish (10A3), dirty pink (10B2), staining reddish-purple (12B5) when damaged and occasionally showing reddish-purple (12B5) spots, short gills or lamellulae narrowed. Stipe 4-8 (-12) cm long, 0.5-1.5 cm diam., central, cylindrical, pinkish-white (10A2), pinkish-purple (12B5), staining reddish-violet (11B5), reddish-brown (10C7-8) when rubbed or with age. Flesh initially firm, becoming soft with age, whitish to pinkish-white (10A2), becoming darker (10A3) when cut or damaged. Basal mycelium white. Odour not distinctive. Taste mild.

Basidiospores [80/3/3] (7-) 7.5-9.5 $\times 4-5 \mu \mathrm{m}, \mathrm{Q}=1.6-2.13, \mathrm{Q}_{\mathrm{m}}=1.86 \pm 0.14$, ellipsoid to oblong, ovoid, smooth under a light microscope and SEM, thin-walled, hyaline, with a distinct hilar appendix, yellowish in Melzer's Reagent. Basidia 38-45 (-50) × 5-10 $\mu \mathrm{m}$, mostly 4-spored, clavate, slender, thin-walled; sterigmata 4-9 $\mu \mathrm{m}$ in length. Cheilocystidia 30-40 $\times 3-6 \mu \mathrm{m}$, rare, scattered, subfusiform, narrowly clavate, spathulate, subcylindrical, flexuous, thin-walled, colourless. Pleurocystidia 43-50 × 3-7 $\mu \mathrm{m}$, rare, scattered, subfusiform, narrowly clavate, spathulate, flexuous, thin-walled, hyaline. Lamellar trama divergent, composed of short elements and long hyphae, short elements 5-12 × 3-6 $\mu \mathrm{m}$, next to hymenium, cylindrical, long ellipsoid, pear-shaped or irregularlyshaped, colourless and hyaline; long hyphae 6-18 $\mu \mathrm{m}$ broad, long ellipsoid, clavate or irregularly-shaped, colourless and hyaline. Pileipellis an ixotrichoderm, consisting of hyphae (3-5 um diam.) in gluten, loosely interwoven, branched or non-branched, thin-walled. Pileal trama made up of thin-walled hyphae 4-20 $\mu \mathrm{m}$ diam. Stipitipellis a cutis, composed of hyphae 3-5 $\mu \mathrm{m}$ diam., thin-walled, mostly arranged in parallel. Stipititrama made up of hyphae 5-18 $\mu \mathrm{m}$ diam., arranged in parallel, thin-walled. Mycelial hyphae 2-5 $\mu \mathrm{m}$ broad, smooth under a light microscope, mostly smooth and occasionally covered with a massive nipple-shaped protuberance under SEM. Clamp connections present in all tissues.

\section{Known distribution}

Yunnan Province.

\section{Habit and habitat}

Solitary to sparsely scattered in broad-leaved forests probably associated with Lyonia ovalifolia and Ternstroemia gymnanthera, elev. 2100-2600 m; in late summer and autumn (August-October). 
Additional materials examined: CHINA. Yunnan Province: Kunming City, Miaogao Temple, elev. 2100 m, 6 August 2006, Y.C. Li 688 (HKAS 50442); Jianchuan Prefecture, Shibao Mountain, 2623.73' N, 99 50.41'E, elev. 2500 m, 17 August 2014, S.D. Yang 12 (MHKMU S.D. Yang 12); the same location, in broad-leaved forests, mainly Ericaceae and Fagaceae, elev. 2590 m, 20 August 2014, J. Zhao 52 (MHKMU J. Zhao 52); the same location, in mixed forests with Ericaceae, Quercus sp. and a few Pinus yunnanensis, $26^{\circ} 23.78^{\prime} \mathrm{N}$, 99 50.32'E, elev. 2530 m, 13 September 2019, M. Mu 439 (MHKMU M. Mu 439); the same location, occurred under Ternstroemia gymnanthera, mixed with Ericaceae (Pieris formosa and Rhododendron decorum), Fagaceae and a few P. yunnanensis, elev. $2530 \mathrm{~m}, 5$ October 2020, H.Y. Huang 969 (MHKMU H.Y. Huang 969), H.Y. Huang 970 (MHKMU H.Y. Huang 970), H.Y. Huang 971 (MHKMU H.Y. Huang 971); Qujing City, Junzi Mountain, in broad-leaved forests mainly dominated by Lyonia ovalifolia, mixed with a few Lithocarpus sp., P. yunnanensis, Quercus sp. and R. decorum, $24^{\circ} 38.03^{\prime} \mathrm{N}, 104^{\circ} 8.98^{\prime} \mathrm{E}$, elev. $2330 \mathrm{~m}, 11$ August 2019, H.Y. Huang 313 (MHKMU H.Y. Huang 313), H.Y. Huang 316 (MHKMU H.Y. Huang 316), H.Y. Huang 321 (MHKMU H.Y. Huang 321), T. Huang 59 (MHKMU T. Huang 59),

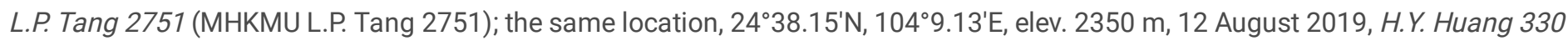
(MHKMU H.Y. Huang 330), H.Y. Huang 334 (MHKMU H.Y. Huang 334), H.Y. Huang 335(MHKMU H.Y. Huang 335), H.Y. Huang 336 (MHKMU H.Y. Huang 336), L.P. Tang 2772 (MHKMU L.P. Tang 2772), L.P. Tang 2773 (MHKMU L.P. Tang 2773); Yongping Prefecture, National Highway 320, 2529.71'N, 99³9.40'E, elev. 2200 m, 30 July 2009, L.P. Tang 1025 (HKAS 56982); Yunlong Prefecture, Nuodeng Village, elev. unknown, 26 August 2011, R. Wang 95 (HKAS 72912).

\section{Comments}

Hygrophorus yunnanensis is distinctive by its small basidiomata, thin context, narrow basidiospores, so far restricted to Yunnan Province and occurring at high elevations $(2100-2600 \mathrm{~m})$. This taxon is common under shrub wood, mainly Lyonia ovalifolia in Junzi Mountain and occasionally occurring under Ternstroemia gymnanthera.

Morphologically, H. yunnanensis is quite similar to H. parvirussula. However, H. parvirussula occurs at high elevations (2500-3300 m) associated with Pieris formosa and Rhododendron concinnum and has wide basidiospores $\left(6.9-9.0 \times 4.6-6.9 \mu \mathrm{m}, \mathrm{Q}=1.13-1.83, \mathrm{Q}_{\mathrm{m}}\right.$ $=1.48 \pm 0.23)$.

The LSU phylogenetic analyses showed that $H$. yunnanensis was sister to $H$. deliciosus, the comparison between $H$. deliciosus and $H$. yunnanensis being found in our treatment of $H$. deliciosus.

Taxonomic Key to Species of Hygrophorus russula Complex

1 Strictly North American distribution, at low elevations $<500$ m; context unchanged on exposure; basidiospores $<3.2 \mu \mathrm{m}$ in width H. russuliformis

$1^{\star}$ Asia and Europe distribution, at high elevations $>500 \mathrm{~m}$; context changed on exposure; basidiospores $>3.2 \mu \mathrm{m}$ in width..... .2

2 East Asia distribution; pileus $>15 \mathrm{~cm}$ diam.; basidiospores small, $5.5-7(-8) \times 3.5-4.8(-5)$ $\mu \mathrm{m}$. H. orientalis

2* Narrow distribution; pileus $<15 \mathrm{~cm}$ diam.; basidiospores slightly large 3

3 Europe distribution, at low elevations $<1500 \mathrm{~m}$; basidiospores large, 8-10 × 5-6.5 $\mu \mathrm{m}$. H. russula

$3^{*}$ SW China distribution, at high elevations $>1500 \mathrm{~m}$; basidiospores small...............4

4 Pileus $>10 \mathrm{~cm}$ diam.; associated with Fagaceae...... .5

4* Pileus $<10 \mathrm{~cm}$ diam.; associated with Ericaceae or Theaceae. 6

5 Scattered to gregarious at elevations $1900-3700 \mathrm{~m}$; pileus applanate, context thick (up to $2.4 \mathrm{~cm}$ ); basidiospores broad ellipsoid to ellipsoid, $6.44-8(-9) \times 4.6-6 \mu \mathrm{m}, \mathrm{Q}_{\mathrm{m}}=1.42 \pm 0.12$ H. deliciosus

5* Solitary or scattered at elevations $2000-2800 \mathrm{~m}$; pileus wavy and uplifted, context thin $(0.4-0.9 \mathrm{~cm})$; varied basidiospores, $6.44-9$ $(-9.5) \times(4-) 4.4-6(-6.5) \mu \mathrm{m}, \mathrm{Q}_{\mathrm{m}}=1.46 \pm 0.14$ H. qinggangjun 
6 Occurring at elevations 2500-3300 m; basidiospores broad ellipsoid, surface bacillate ornamentation, 6.9-9.0 × 4.6-6.6 (-6.9) $\mu$ m, $\mathrm{Q}_{\mathrm{m}}=1.48 \pm 0.23$ ..H. parvirussula

6* Occurring at elevations 2100-2600 m; basidiospores narrow ellipsoid, surface smooth, $(7-) 7.5-9.5 \times 4-5 \mu \mathrm{m}, \mathrm{Q}_{\mathrm{m}}=1.86 \pm$

0.14 .H. yunnanensis

\section{Discussion}

\section{Species delimitations of Hygrophorus russula complex}

Due to its recognisable characteristics in the field, consisting of a pale flesh pink to reddish-purple pileus, $H$. russula was once considered a widely-distributed species in the Northern Hemisphere (Hongo 1982; Bas et al. 1990; Hesler and Smith 1963; Chen and Li 2013). With the application of molecular methods, seven molecularly-distinct species have been revealed to be hidden under this name, supported by diagnosable criteria, including morphological characters, ecological traits and geographical distribution (see Table 2). Three species, $H$. orientalis, $H$. qinggangjun and $H$. yunnanensis from China, are newly described in this study.

Table 2

Comparison of the diagnostic characteristics between Hygrophorus russula complex

\begin{tabular}{|c|c|c|c|c|c|c|c|}
\hline & H. deliciosus & H. orientalis & $\begin{array}{l}H . \\
\text { parvirussula }\end{array}$ & $\begin{array}{l}H . \\
\text { qinggangjun }\end{array}$ & H. russula & $\begin{array}{l}H . \\
\text { russuliformis }\end{array}$ & $\begin{array}{l}H . \\
\text { yunnanensis }\end{array}$ \\
\hline Pileus & $\begin{array}{l}5-14 \mathrm{~cm} \\
\text { applanate }\end{array}$ & $\begin{array}{l}\text { 9-25 cm, } \\
\text { with an in-rolled } \\
\text { margin }\end{array}$ & $\begin{array}{l}6-8(-10) \mathrm{cm} \\
\text { applanate }\end{array}$ & $\begin{array}{l}\text { 8-14 cm, } \\
\text { margin } \\
\text { wavy and } \\
\text { uplifted }\end{array}$ & $\begin{array}{l}4-10(-15) \\
\text { cm, applanate }\end{array}$ & $\begin{array}{l}5-8 \mathrm{~cm} \\
\text { convex }\end{array}$ & $\begin{array}{l}\text { 4-8 cm, } \\
\text { applanate }\end{array}$ \\
\hline Lamellae & $\begin{array}{l}60-75 \\
\text { pieces } \\
0.5-1 \mathrm{~cm} \\
\text { deep }\end{array}$ & $\begin{array}{l}120-145 \text { pieces } \\
0.5-1 \mathrm{~cm} \text { deep }\end{array}$ & $\begin{array}{l}60-80 \text { pieces } \\
0.4-0.9 \mathrm{~cm} \\
\text { deep }\end{array}$ & $\begin{array}{l}60-80 \\
\text { pieces } \\
0.9-1.2 \mathrm{~cm} \\
\text { deep }\end{array}$ & $\begin{array}{l}70-150 \\
\text { pieces } \\
\text { up to } 0.5 \mathrm{~cm} \\
\text { deep }\end{array}$ & $\begin{array}{l}\text { Crowded, } \\
\text { unknown } \\
\text { Narrow, } \\
\text { unknown }\end{array}$ & $\begin{array}{l}70-95 \\
\text { pieces } \\
0.3-0.8 \mathrm{~cm} \\
\text { deep }\end{array}$ \\
\hline Stipe & $\begin{array}{l}7-12 \times 1- \\
2.2\end{array}$ & $7-15 \times 2.5-5$ & $\begin{array}{l}6.5-13 \times 0.5- \\
1.5\end{array}$ & $\begin{array}{l}7-10 \times 1- \\
1.7\end{array}$ & $\begin{array}{l}6-10(-15) \times \\
0.8-2.5(-4)\end{array}$ & $1-4 \times 1.4-2$ & $\begin{array}{l}4-8(-12) \times \\
0.5-1.5\end{array}$ \\
\hline $\begin{array}{l}\text { Context } \\
(\mathrm{cm})\end{array}$ & Up to 2.4 & Up to 3 & $0.4-1$ & $0.4-0.9$ & Up to 2.5 & Unknown & $0.3-0.7$ \\
\hline $\begin{array}{l}\text { Spores } \\
(\mu \mathrm{m})\end{array}$ & $\begin{array}{l}6.44-8(-9) \\
\times 4.6-6\end{array}$ & $\begin{array}{l}5.5-7(-8) \times \\
3.5-4.8(-5)\end{array}$ & $\begin{array}{l}6.9-9.0 \times \\
4.6-6.6(-6.9)\end{array}$ & $\begin{array}{l}6.44-9(- \\
9.5) \times(4-) \\
4.4-6(- \\
6.5)\end{array}$ & $8-10 \times 5-6.5$ & $\begin{array}{l}8-10(-12) \\
\times 2-3.2\end{array}$ & $\begin{array}{l}(7-) 7.5-9.5 \\
\times 4-5\end{array}$ \\
\hline $\mathrm{Q}_{\mathrm{m}}$ & $1.42 \pm 0.12$ & $1.57 \pm 0.15$ & $1.48 \pm 0.23$ & $1.46 \pm 0.14$ & $1.55 \pm 0.12$ & Unknown & $1.86 \pm 0.14$ \\
\hline $\begin{array}{l}\text { Basidia } \\
(\mu \mathrm{m})\end{array}$ & $\begin{array}{l}45-55 \times 4- \\
7\end{array}$ & $30-40 \times 4-7$ & $30-55 \times 5-10$ & $\begin{array}{l}43-49 \times 6- \\
9\end{array}$ & $\begin{array}{l}55-68(-80) \\
\times 7-9\end{array}$ & $38-57 \times 5-7$ & $\begin{array}{l}38-45(-50) \\
\times 5-10\end{array}$ \\
\hline Habit & $\begin{array}{l}\text { Scattered to } \\
\text { gregarious }\end{array}$ & $\begin{array}{l}\text { scattered to } \\
\text { gregarious, at } \\
\text { times in arcs or } \\
\text { fairy rings }\end{array}$ & $\begin{array}{l}\text { Solitary or } \\
\text { scattered }\end{array}$ & $\begin{array}{l}\text { Solitary or } \\
\text { scattered }\end{array}$ & $\begin{array}{l}\text { Solitary to } \\
\text { subgregarious }\end{array}$ & Unknown & $\begin{array}{l}\text { Solitary to } \\
\text { sparsely } \\
\text { scattered }\end{array}$ \\
\hline Hosts & $\begin{array}{l}\text { Quercus } \\
\text { aquifolioides }\end{array}$ & $\begin{array}{l}\text { Cyclobalanopsis } \\
\text { sp. } \\
\text { Q. mongolica }\end{array}$ & $\begin{array}{l}\text { Pieris formosa } \\
\text { Rhododendron } \\
\text { concinnum }\end{array}$ & $\begin{array}{l}\text { Quercus sp. } \\
\text { (maybe Q. } \\
\text { serrata) }\end{array}$ & Q. ilex & oak & $\begin{array}{l}\text { Lyonia } \\
\text { ovalifolia } \\
\text { Ternstroemia } \\
\text { gymnanthera }\end{array}$ \\
\hline
\end{tabular}

Morphologically, H. russula complex has similar colours (pale reddish-purple, dark red, reddish-brown, brownish-vinaceous), which are hard to identify in the field. Still, they are divergent in geographical distribution, host information, the size of basidiomata and microscopic characters.

Three species, $H$. parvirussula, $H$. russuliformis and $H$. yunnanensis, have a similar pileus less than $10 \mathrm{~cm}$ diam. However, $H$. russuliformis, so far restricted to North America, occurs under oak trees at low elevations (less than $500 \mathrm{~m}$ ) of Florida, the context is 
unchanged on exposure and has narrower basidiospores measuring 8-10 $(-12) \times 2-3.2 \mu \mathrm{m}$ (Hesler and Smith 1963). Hygrophorus parvirussula and $H$. yunnanensis were both found in south-western China and the context became darker on exposure.

Regarding $H$. deliciosus, $H$. qinggangjun and $H$. russula, these species are medium-sized with pileus $5-15 \mathrm{~cm}$ diam. However, $H$. russula occurs at low elevations ( $<1100 \mathrm{~m}$ ), has narrow lamellae (up to $0.5 \mathrm{~cm}$ wide) and large basidiospores $(8-10 \times 5-6.5 \mu \mathrm{m})(\mathrm{Bas}$ et al. 1990; Candusso 1997). Both Hygrophorus deliciosus and $H$. qinggangjun were found at high elevations $(>2500 \mathrm{~m})$, have shorter basidia $(43-49 \times 6-9 \mu \mathrm{m} ; 45-55 \times 4-7 \mu \mathrm{m})$ and broader basidiospores $[6.44-9(-9.5) \times(4-) 4.4-6(-6.5) \mu \mathrm{m}, \mathrm{Q}=(1.15-) 1.24-1.64$ (-1.89), $\left.Q_{m}=1.46 \pm 0.14 ; 6.44-8(-9) \times 4.6-6 \mu \mathrm{m}, \mathrm{Q}=1.25-1.6, \mathrm{Q}_{\mathrm{m}}=1.42 \pm 0.12\right]$.

Hygrophorus orientalis differs from other species in the H. russula complex by its extensive distribution, wide range of elevation (750$2340 \mathrm{~m}$ ), scattered to gregarious, at times in arcs or fairy rings, probably associated with Cyclobalanopsis sp. or Quercus mongolica, larger basidiomata (pileus up to $25 \mathrm{~cm}$ diam., stipe up to $15 \mathrm{~cm}$ long, $5 \mathrm{~cm}$ diam.), more dense lamellae (120-145 pieces/cap), shorter basidia $(30-40 \times 4-7 \mu \mathrm{m})$ and smaller basidiospores [5.5-7 (-8) × 3.5-4.8 $(-5) \mu \mathrm{m}]$.

\section{Ecological traits of species in the Hygrophorus russula complex}

Our data indicate that ecological traits, including its range of elevation, distribution and host preference, are useful for separating morphologically-similar species in the H. russula complex. European Hygrophorus russula was probably associated with Quercus ilex (Bas et al. 1990; Candusso 1997). Hygrophorus russuliformis from North America occurs under oak trees in Florida (Hesler and Smith 1963). To date, there are five taxa of the $H$. russula complex from Yunnan, China. Their distributions show a distinct pattern, varying with the elevation gradient. Hygrophorus orientalis is widely distributed, but in low-elevation environments. Hygrophorus qinggangjun and $H$. yunnanensis seem to be restricted to high elevations between 2000-3000 m. H. deliciosus and H. parvirussula can be found only in the subalpine belt (above $3000 \mathrm{~m}$ ). This distribution usually correlates with the host plant. Our field records indicate that $H$. yunnanensis is associated with Lyonia ovalifolia and Ternstroemia gymnanthera, which grows in forests below $2800 \mathrm{~m} ; H$. deliciosus is connected to Quercus aquifolioides and H. parvirussula is associated with Pieris formosa and Rhododendron concinnum, both their host plants being distributed at high elevations above $3000 \mathrm{~m}$ (see Fig. 14).

\section{The taxonomic importance of comprehensive data in the Hygrophorus russula complex}

Due to the similar characteristics, it is quite difficult to identify the species complex. Thus, the application of comprehensive evidence is very important for the accurate identification of this species complex. In our study, SEM characteristics and chemical reactions are helpful to distinguish the complex species of $H$. russula. Hygrophorus parvirussula is characterised by bacillate ornamentation of basidiospores under SEM; the other four taxa in this complex are smooth (see Fig. 7). The characteristics of basal hyphae are not very common in fungal taxonomy. Huang et al. (2020) firstly reported abundant morphological characters of the basal hyphae of seven species from Clavaridelphus as taxonomical evidence. In H. russula complex, the basal hyphae also vary from smooth to a massive nipple-shaped protuberance under SEM (see Fig. 10). It indicates the basal hyphae are valuable in the classification of Hygrophorus. In terms of chemical reactions, we found that $\mathrm{C}_{6} \mathrm{H}_{5} \mathrm{OH}$ can be used to distinguish the Hygrophorus species.

Molecular methods effectively detect hidden species in fungi (Tang et al. 2014, 2017; Huang et al. 2018; Yang et al. 2018). In addition, disentangling the species complex of $H$. russula needs many different types of information, including a phylogenetic, morphological and taxonomical investigation. SEM characteristics and chemical reactions help distinguish and separate species.

\section{Declarations}

\section{Acknowledgements}

We thank the curators and collectors of AH, HKAS, HMAS and RBGE. We are greatly indebted to those colleagues for kindly supplying photos: Prof. Bai Wang from Changbai Mountain Academy of Sciences; Drs. Qing Cai, Qi Zhao, Yan-Jia Hao, Ting Guo, Xue-Tai Zhu, Yan-Chun Li, Zhu-Liang Yang from HKAS; and Miss Jie Zhao, Man Mu and Shu-Da Yang from KMU. The authors appreciate Zhi-Jia Gu from HKAS who assisted in the work of the scanning electron microscope (SEM).

\section{Authors' contributions}

All authors contributed to the study conception and design. Material preparation, sampling, collecting, DNA isolation and preparation for sequencing were performed by Hong-Yan Huang, Li-Ping Tang, Moreno Gabriel, Tie-Zhi Liu, Ting Huang and Wen-Hao Zhang. Data 
analysis were performed by Hong-Yan Huang. The first draft of the manuscript was written by Hong-Yan Huang and all authors commented on previous versions of the manuscript. All authors read and approved the final manuscript.

\section{Availability of data and materials}

The datasets generated during and/or analysed during the current study are available in the GenBank, http://www.ncbi.nlm.nih.gov.

Ethics declarations

\section{Conflict of interest}

The authors declare that they have no conflict of interest.

\section{Consent for publication}

Not applicable

\section{Ethical approval and Consent to participate}

Not applicable

\section{Funding}

This work was financially supported by the National Natural Science Foundation of China (Nos. 31960007, 31560004, 31760004); Digitalisation, development and application of biotic resource (No. 202002AA100007); and the Programme Innovative Research Team in Science and Technology in Yunnan Province (No. 202005AE160004).

\section{References}

1. Agerer R (2012) Asexual reproduction of Hygrophorus olivaceoalbus by intracellular microsclerotia in root cells of Picea abies-a winner of ozone. stress? Mycological Progress 11:425-434. https://doi.org/10.1007/s11557-011-0757-y

2. Bas C, Noordeloos ME, Kuyper ThW, Vellinga EC (1990) Flora agaricina neerlandica vol. 2: critical monographs on families of agarics and boleti occurring in the Netherlands. Balkema AA, Rotterdam, 115-133

3. Candusso M (1997) Hygrophorus s.l., Fungi Europaei 6. Libreria Basso, Alassio, pp 207-211

4. Chen JL, Li Y (2013) The checklist of species in Hygrophoraceae from China and their distribution. Journal of Fungal Research 11:3-13, 37 [in Chinese]

5. Doyle JJ, Doyle JL (1987) A rapid DNA isolation procedure for small quantities of fresh leaf material. Phytochem Bull 19:11-15

6. Edgar RC (2004) MUSCLE: multiple sequence alignment with high accuracy and high throughput. Nucleic Acids Res 32:17921797

7. Endo N, Tokoo R, Fukuda M, Yamada A (2018) Hygrophorus yukishiro sp. nov., a new vernal edible mushroom from Nagano Prefecture. Japan Mycoscience 59:449-454. https://doi.org/10.1016/j.myc.2018.03.002

8. Fries EM (1821) Systema Mycologicum. Vol. 1. Lund and Griefswald

9. Gillet CC (1878) Les Champignons qui croissent en France. Description et iconographie, propiétés utiles ou vénéneuses. J.B. Baillère \& fils, Paris

10. Hall TA (1999) BioEdit: a user-friendly biological sequence alignment editor and analyses program for Windows $95 / 98 / N T$. Nucleic Acids Symposium Series 41:95-98

11. Hesler LR, Smith H (1963) North American species of Hygrophorus. The University of Tennessee Press, Knoxville

12. Hongo T (1982) Hygrophoraceae of Japan. Memoirs of the Faculty of Liberal Arts and Education. Shiga University 32:85-92

13. Huang HY, Yang SD, Zeng NK, Zhang GL, Hu Y, Tang LP (2018) Hygrophorus parvirussula sp. nov., a new edible mushroom from southwestern China. Phytotaxa 373:139-146. https://doi.org/10.11646/phytotaxa.373.2.4

14. Huang HY, Zhao J, Zhang P, Ge ZW, Li X, Tang LP (2020) The genus Clavariadelphus (Clavariadelphaceae, Gomphales) in China. Mycokeys 70:89-121. http://doi.org/10.3897/mycokeys.70.54149 
15. Jacobsson S, Larsson E (2007) Hygrophorus penarioides, a new species identified using morphology and ITS sequence data. Mycotaxon 99:337-343

16. Kauffman CH (1918) The Agaricaceae of Michigan. Publications Michigan Geology Biology Survey, Biology Series 5 26. Wynkoop, Lansing, Hallenbeck Crawford Co. 185

17. Kornerup A, Wanscher JH (1981) Taschenlexikon der Farben. 3. Aufl. Muster-Schmidt Verlag, Göttingen

18. Lanfear R, Frandsen PB, Wright AM, Senfeld T, Calcott B (2016) PartitionFinder 2: new methods for selecting partitioned models of evolution for molecular and morphological phylogenetic analyses. Mol Biol Evol 34:772-773.

https://doi.org/10.1093/molbev/msw260

19. Larsson E, Jacobsson S (2004) Controversy over Hygrophorus cossus settled using ITS sequence data from 200-year-old type material. Mycol Res 108:781-786

20. Larsson E, Kleine J, Jacobsson S, Krikorev M (2018) Diversity within the Hygrophorus agathosmus group (basidiomycota, agaricales) in northern Europe. Mycological Progress 17:1293-1304. https://doi.org/10.1007/s11557-018-1445-y

21. Larsson E, Bendiksen K (2020) Hygrophorus betulae, a new species described from subalpine birch forest in Finland. Karstenia 58:1-9. https://doi.org/10.29203/ka.2020.484

22. Lodge DJ, Padamsee M, Matheny PB, Aime MC, Cantrell SA, Boertmann D, Kovalenko A, Vizzini A, Dentinger BTM, Kirk PM, Ainsworth AM, Moncalvo JM, Vilgalys R, Larsson E, Lücking R, Griffith GW, Smith ME, Norvell LL, Desjardin DE, Redhead SA, Ovrebo CL, Lickey EB, Ercole E, Hughes KW, Courtecuisse R, Young A, Binder M, Minnis AM, Lindner DL, Ortiz-Santana B, Haight J, Læssøe T, Baroni TJ, Geml J, Hattori T (2014) Molecular phylogeny, morphology, pigment chemistry and ecology in Hygrophoraceae (Agaricales). Fungal Divers 64:1-99. https://doi.org/10.1007/s13225-013-0259-0

23. Marino ED (2008) Hygrophorus penarius on beech: between mutualism and parasitism? In: Marino ED, Montecchio L, Agerer $R$ (Eds.) The ectomycorrhizal community structure in beech coppices of different age. Tesi di Dottorato, 84-112

24. Moreau PA, Bellanger JM, Lebeuf R, Athanassiou Z, Athanasiades A, Lambert H, Schwarz C, Larsson E, Loizides M (2018) Hidden diversity uncovered in Hygrophorus sect. Aurei (Hygrophoraceae), including the Mediterranean $\mathrm{H}$. meridionalis and the north American H. boyeri, spp. nov. Fungal Biology 122:817-836. https://doi.org/10.1016/j.funbio.2018.04.009

25. Naseer A, Khalid AN, Healy R, Smith ME (2019) Two new species of Hygrophorus from temperate Himalayan Oak forests of Pakistan. MycoKeys 56:33-47. https://doi.org/10.3897/mycokeys.56.30280

26. Osmundson TW, Robert VA, Schoch CL, Baker LJ, Smith A, Robich G, Miz-zan L, Garbelotto MM (2013) Filling Gaps in Biodiversity Knowledge for Macrofungi: Contributions and Assessment of an Herbarium Collection DNA Barcode Sequencing Project. PLoS ONE 8(4):e62419. https://doi.org/10.1371/journal.pone.0062419

27. Rambaut A, Drummond AJ, Xie D, Baele G, Suchard MA (2018) Posterior summarisation in Bayesian phylogenetics using Tracer 1.7. Syst Biol 67:901-904. https://doi.org/10.1093/sysbio/syy032

28. Ronquist F, Teslenko M, Mark P, Ayres DL, Darling A, Höhna S, Larget B, Liu L, Suchard MA, Huelsenbeck JP (2012) MrBayes 3.2: efficient Bayesian phylogenetic inference and model choice across a large model space. Syst Biol 61:539-542.

https://doi.org/10.1093/sysbio/sys029

29. Schaeffer JC (1774) Fungorum qui in Bavaria et Palatinatu Nascuntur Icones. 58 [in Latin]

30. Sesli E, Antonin V, Contu M (2018) A new species of Hygrophorus, H. yadigarii sp. nov. (Hygrophoraceae) with an isolate systematic position within the genus from the Colchic part of Turkey. Turkish Journal of Botany 42:224-232.

https://dx.doi.org/10.3906/bot-1706-64

31. Siegel N, Schwarz C (2016) Mushrooms of the Redwood Coast. Ten Speed Press, Berkeley, pp 270-279

32. Stamatakis A, Hoover P, Rougemont J (2008) A rapid bootstrap algorithm for the RAxML Web servers. Syst Biol 57:758-771. https://doi.org/10.1080/10635150802429642

33. Stephenson SL, Ali MBHB, Rollins AW, Furches MS, Atherton KR (2017) Ectomycorrhizal Fungi Associated with American Chestnut at a Site in Tennessee, USA. Castanea 82:2-7. https://doi.org/10.2179/16-101

34. Tang LP, Hao YJ, Cai Q, Tolgor, Yang ZL (2014) Morphological and molecu-lar evidence for a new species of Rhodotus from tropical and subtropical Yunnan, China. Mycological Progress 13:45-53. http://dx.doi.org/10.1007/s11557-013-0890-x

35. Tang LP, Lee SS, Zeng NK, Cai Q, Zhang P, Yang ZL (2017) Notes on Amanita sect. Caesareae from Malaysia Mycologia 109:557567

36. https://doi.org/10.1080/00275514.2017.1394789

Page 19/34 
37. Tedersoo L, May TW, Smith ME (2010) Ectomycorrhizal life style in fungi: global diversity, distribution, and evolution of phylogenetic lineages. Mycorrhiza 20:217-263. https://doi.org/10.1007/s00572-009-0274-x

38. Vilgalys R, Hester M (1990) Rapid genetic identification and mapping of enzymatically amplified ribosomal DNA from several Cryptococcus species. J Bacteriol 172:4238-4246

39. https://doi.org/10.1128/jb.172.8.4238-4246.1990

40. Wang CQ, Li TH (2020) Hygrophorus deliciosus (Hygrophoraceae, Agaricales), a popular edible mushroom of the H. russulacomplex from southwestern China. Phytotaxa 449:232-242. https://doi.org/10.11646/phytotaxa.449.3.3

41. Wang EJ, Jeon SM, Jang Y, Ka KH (2016) Mycelial Growth of Edible Ectomycorrhizal Fungi According to Nitrogen Sources. The Korean Journal of Mycology 44:166-170. https://doi.org/10.4489/KJM.2016.44.3.166

42. White TJ, Bruns T, Lee S, Taylor J (1990) Amplification and direct sequencing of fungal ribosomal RNA genes for phylogenies. In: Innis MA, Gelfand DH, Sninsky JJ, White TJ (eds) PCR protocols: a guide to methods and applications. Academic Press, New York, pp 315-322 In.

43. http://dx.doi.org/10.1016/B978-0-12-372180-8.50042-1

44. Yang SD, Huang HY, Zhao J, Zeng NK, Tang LP (2018) Ossicaulis yunnanensis sp. nov. (Lyophyllaceae, Agaricales) from southwestern China. Mycoscience 59:33-37. https://doi.org/10.1016/j.myc.2017.07.008

\section{Figures}




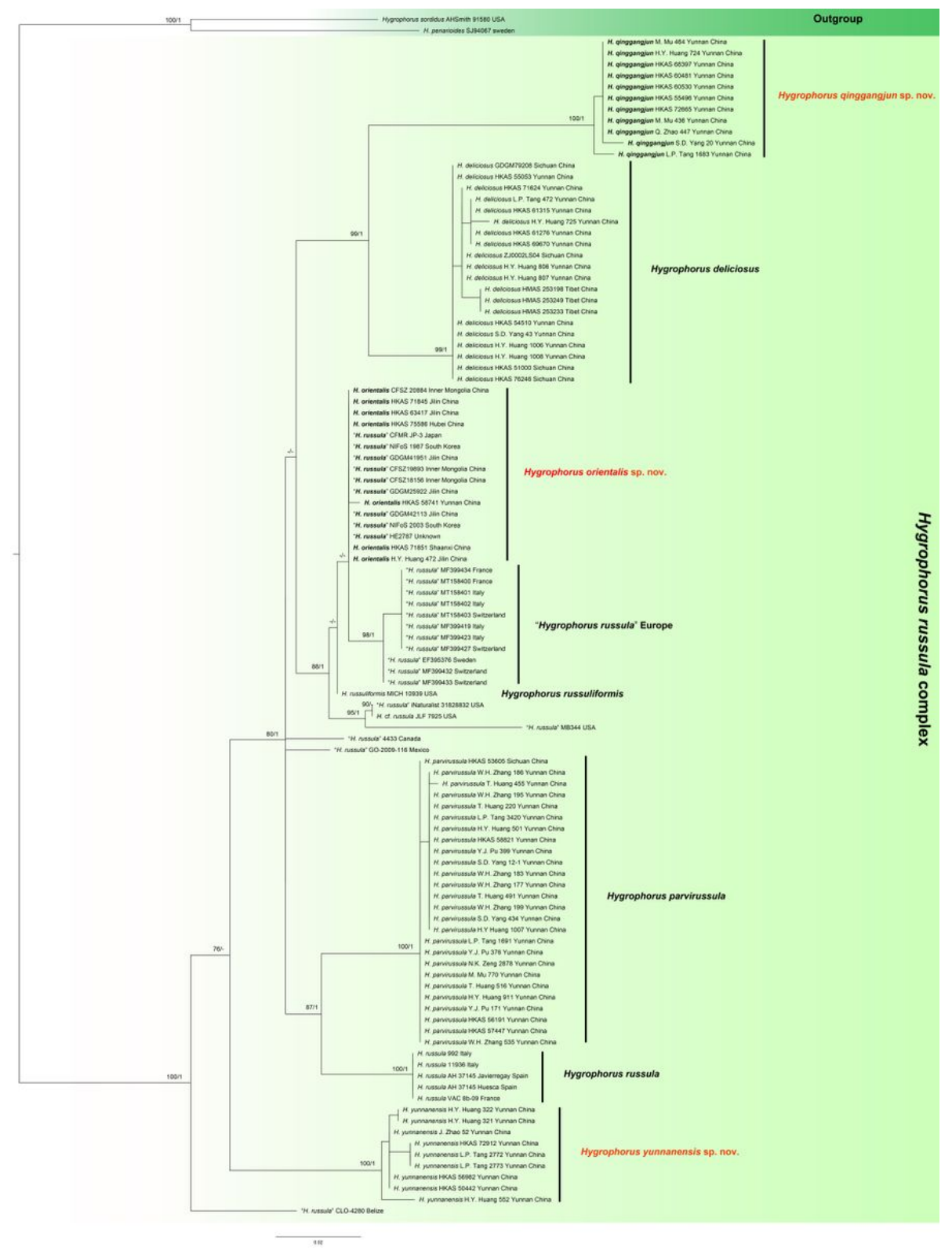

\section{Figure 1}

Phylogenetic tree of Hygrophorus russula complex, based on ITS sequence data. RAxML BP values ( $\geq 70 \%)$ are shown above branches, Bayesian posterior probabilities $(\geq 0.90)$ are shown above branches 


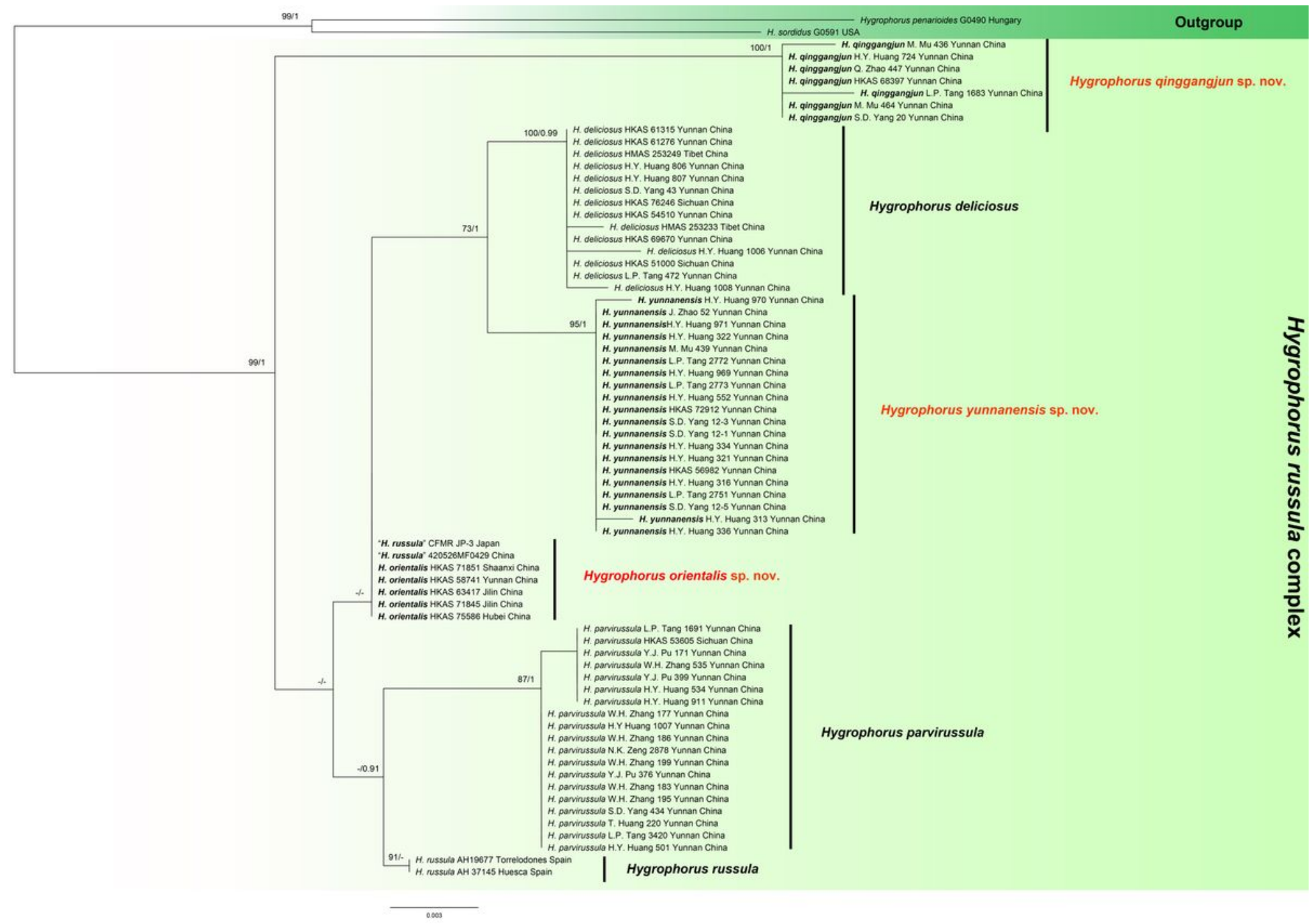

\section{Figure 2}

Phylogenetic tree of Hygrophorus russula complex, based on LSU sequence data. RAxML BP values ( $\geq 70 \%)$ are shown above branches, Bayesian posterior probabilities $(\geq 0.90)$ are shown above branches 


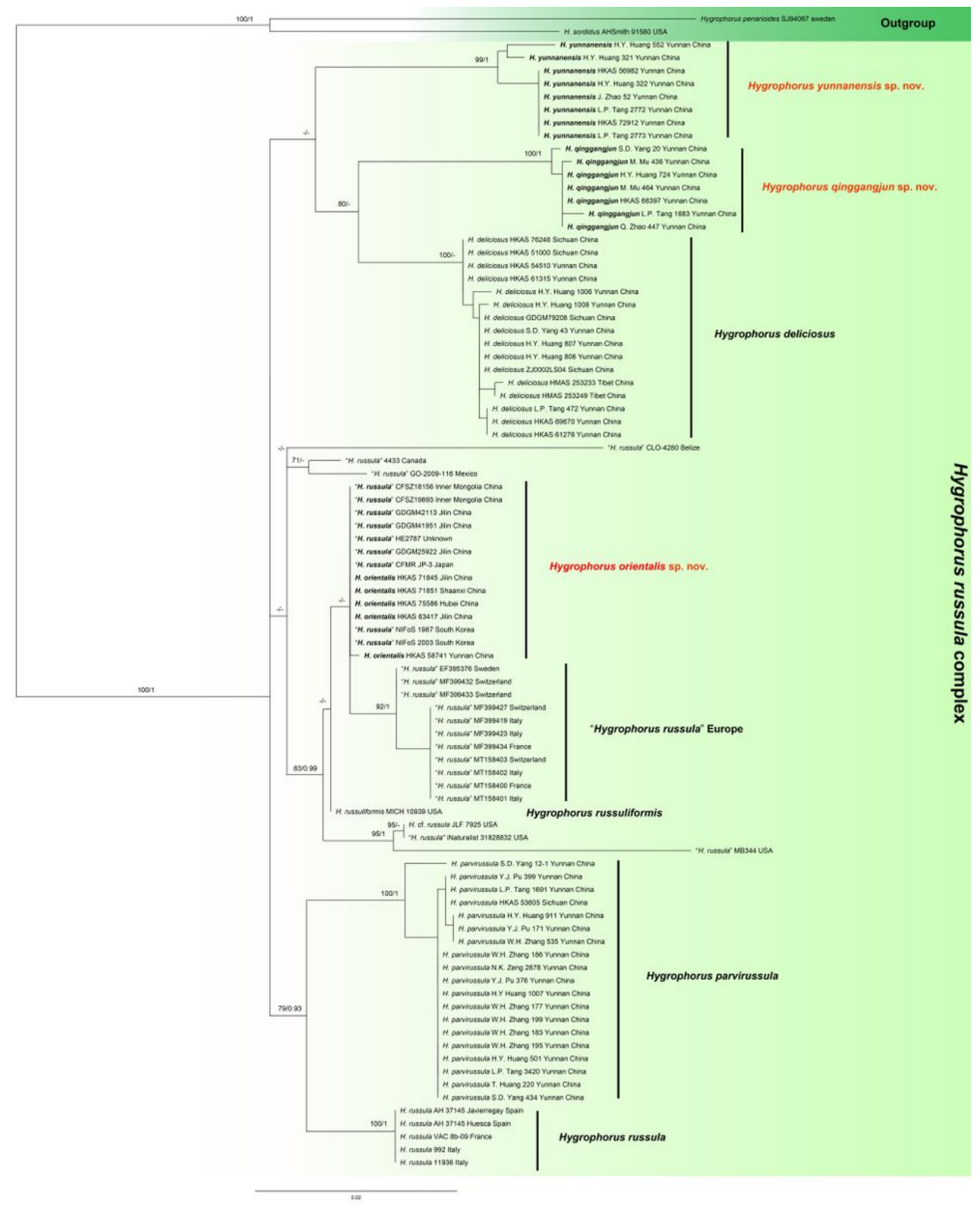

\section{Figure 3}

Phylogenetic tree of Hygrophorus russula complex, based on ITS and LSU sequence data. RAxML BP values ( $\geq 70 \%)$ are shown above branches, Bayesian posterior probabilities $(\geq 0.90)$ are shown above branches 


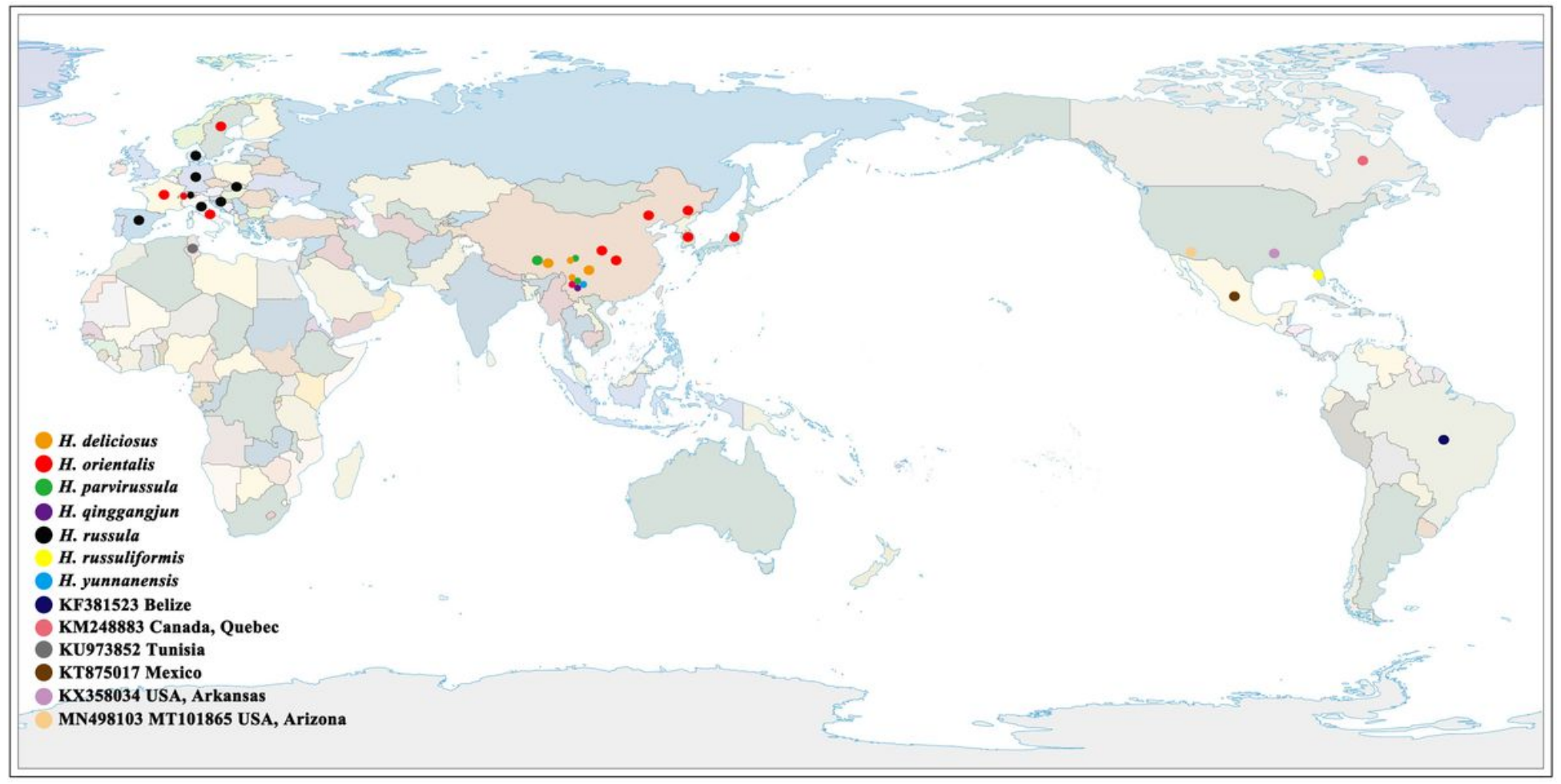

\section{Figure 4}

Distribution of Hygrophorus russula complex. Note: The designations employed and the presentation of the material on this map do not imply the expression of any opinion whatsoever on the part of Research Square concerning the legal status of any country, territory, city or area or of its authorities, or concerning the delimitation of its frontiers or boundaries. This map has been provided by the authors. 

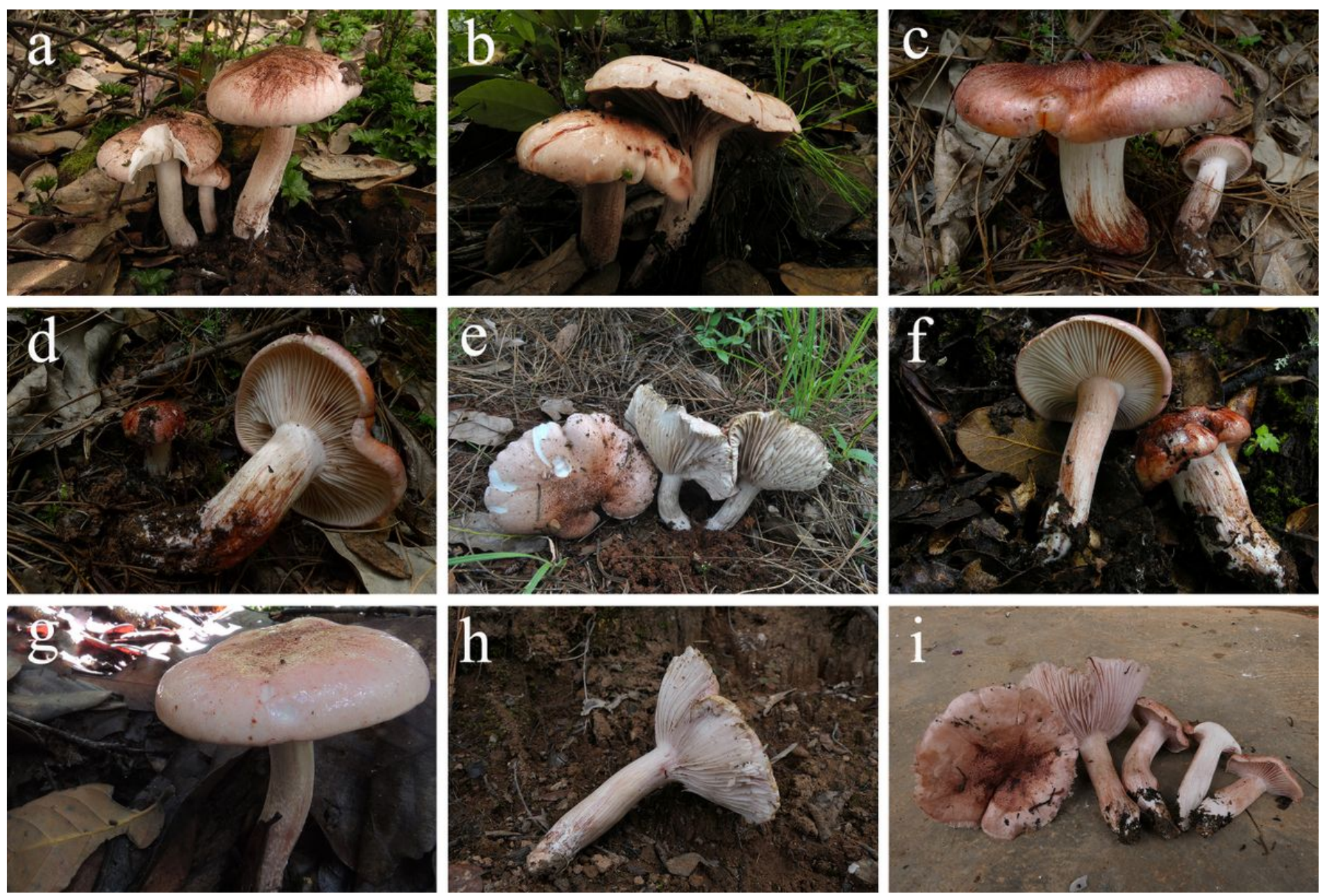

\section{Figure 5}

Basidiomata of Hygrophorus deliciosus. a. from HKAS 54510; b. from HKAS 54703; c, d. from HKAS 71624; e. from HKAS 69670; f. from HKAS 76246; g. from MHKMU S.D. Yang 43; h. from MHKMU H.Y. Huang 1006; i. from MHKMU H.Y. Huang 806 (a photo by Z.L. Yang; b photo by L.P. Tang; c, d photos by J.Y. Hao; e photo by Q. Zhao; f photo by T. Guo; g photo by S.D. Yang; h-i photos by H.Y. Huang) 

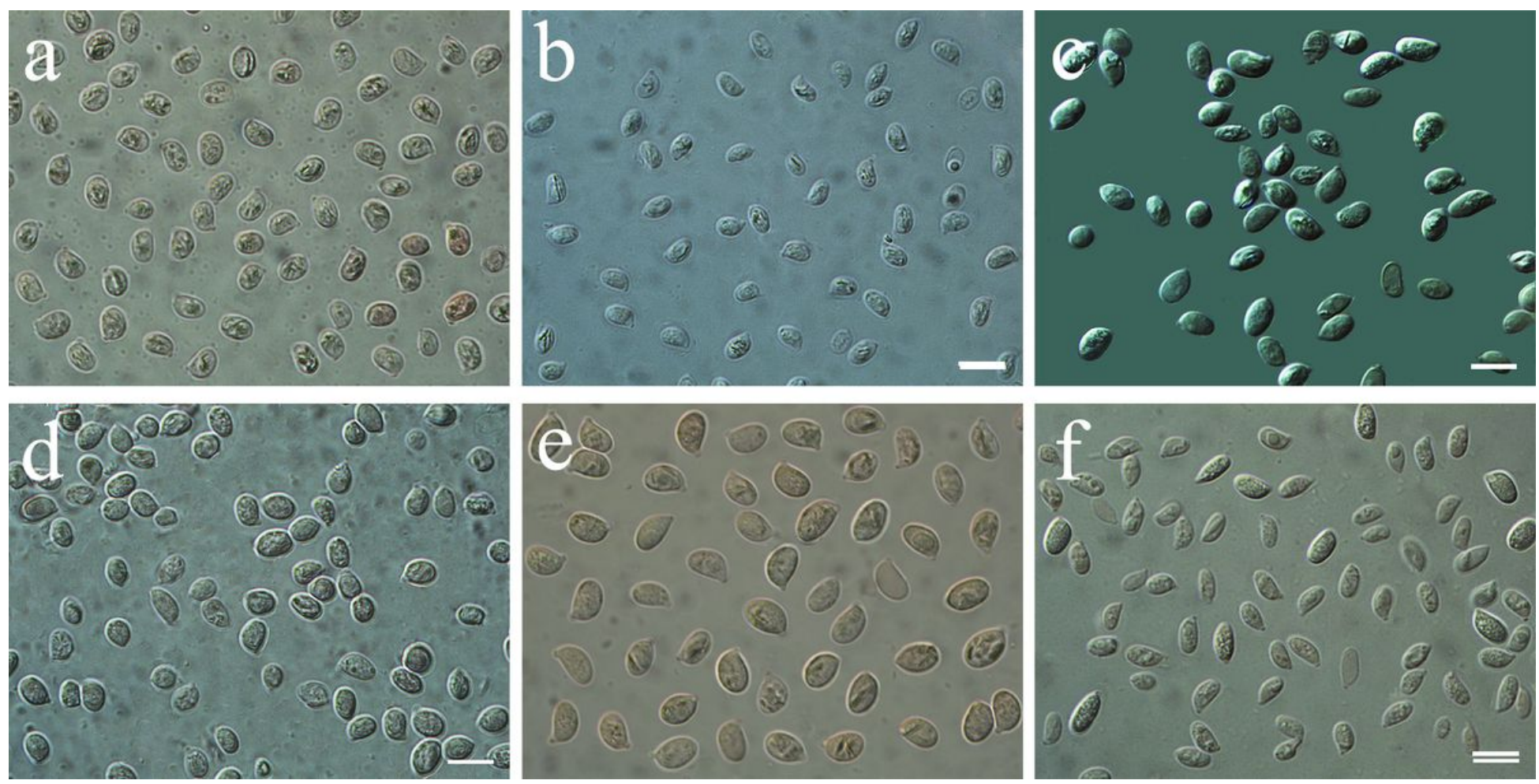

\section{Figure 6}

Basidiospores of Hygrophorus russula complex under a light microscope. a. H. deliciosus (HKAS 61315); b. H. orientalis (MHKMU H.Y. Huang 472); c. H. parvirussula (MHKMU N.K. Zeng 2878); d. H. qinggangjun (MHKMU L.P. Tang 1683); e. H. russula (AH 19677); f. H. yunnanensis (MHKMU S.D. Yang 12). Bars $=10 \mu \mathrm{m}$ 

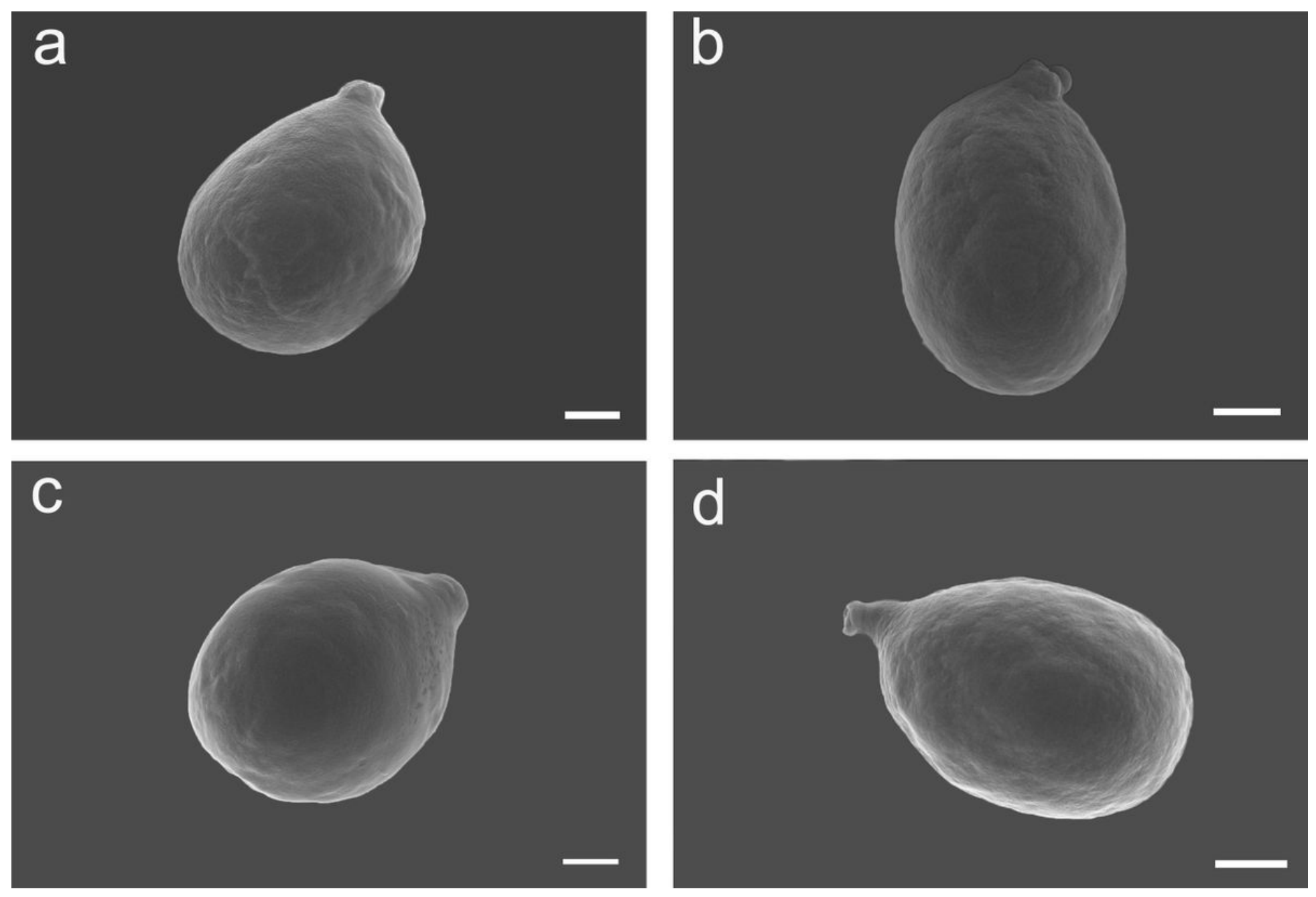

\section{Figure 7}

Basidiospores of Hygrophorus russula complex under SEM. a. H. deliciosus (HKAS 54510); b. H. orientalis (HKAS 75586); c. H. qinggangjun (HKAS 60530); d. H. yunnanensis (MHKMU S.D. Yang 12). Bars $=1 \mu \mathrm{m}$ 

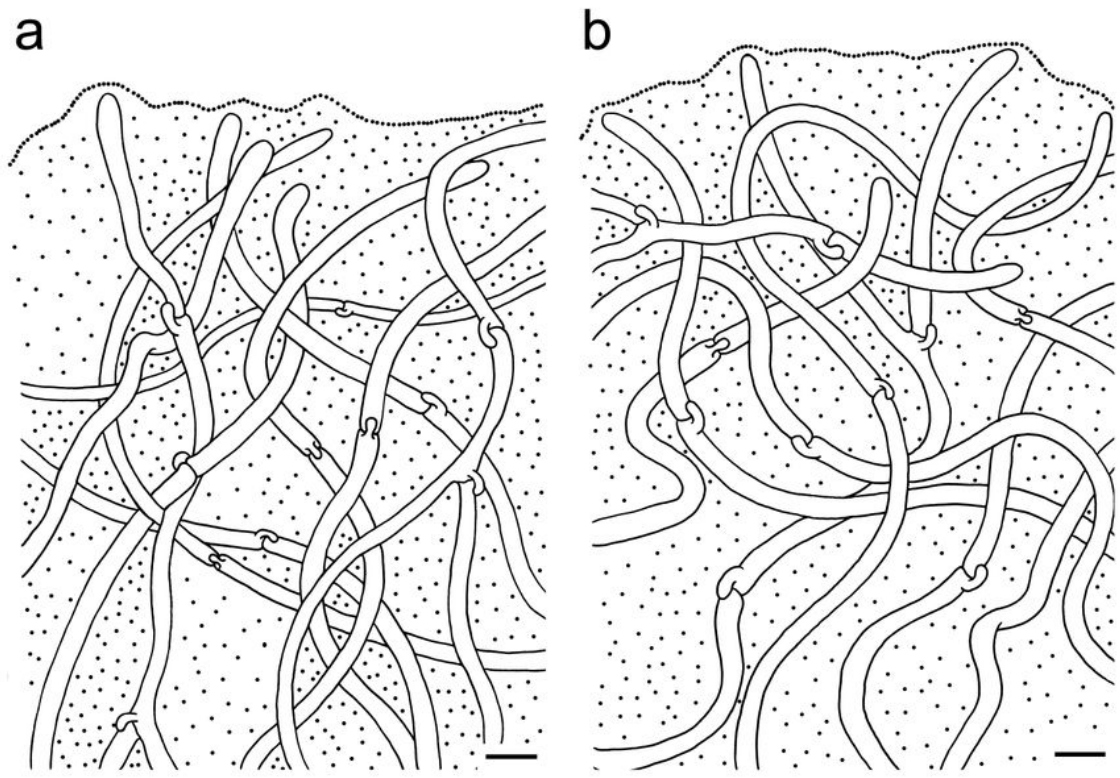

C

d
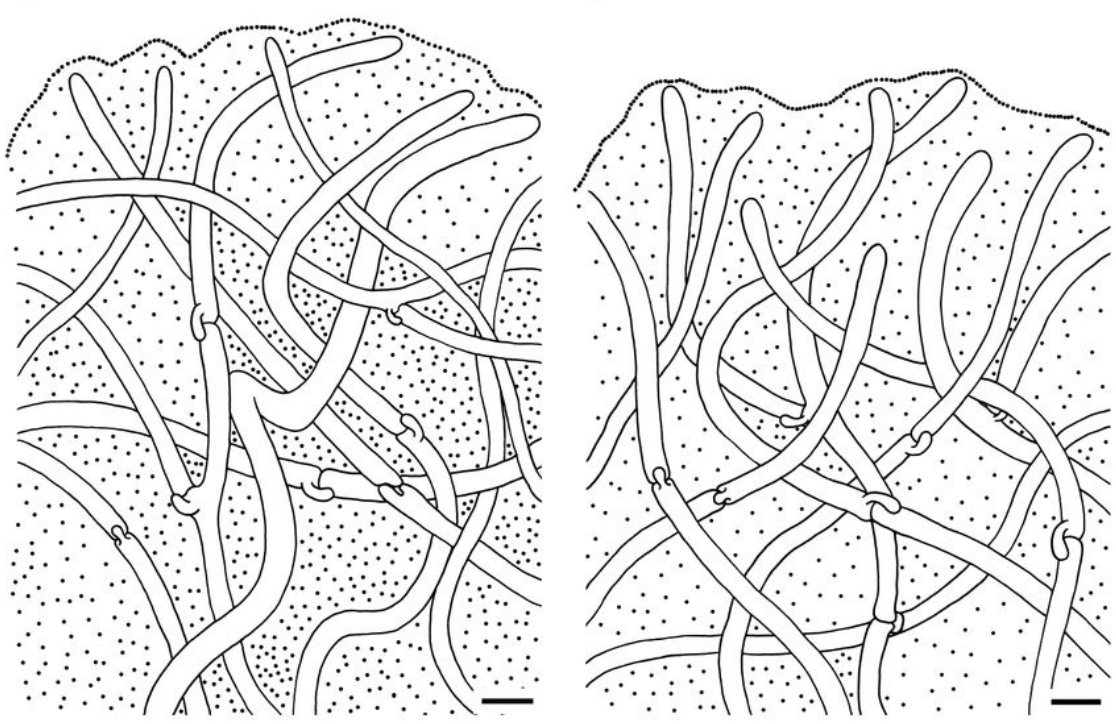

Figure 8

Pileipellis of Hygrophorus russula complex. a. H. deliciosus (HKAS 54510); b. H. orientalis (HKAS 63417); c. H. qinggangjun (MHKMU L.P. Tang 1683); d. H. yunnanensis (HKAS 50442). Bars $=10 \mu \mathrm{m}$ 

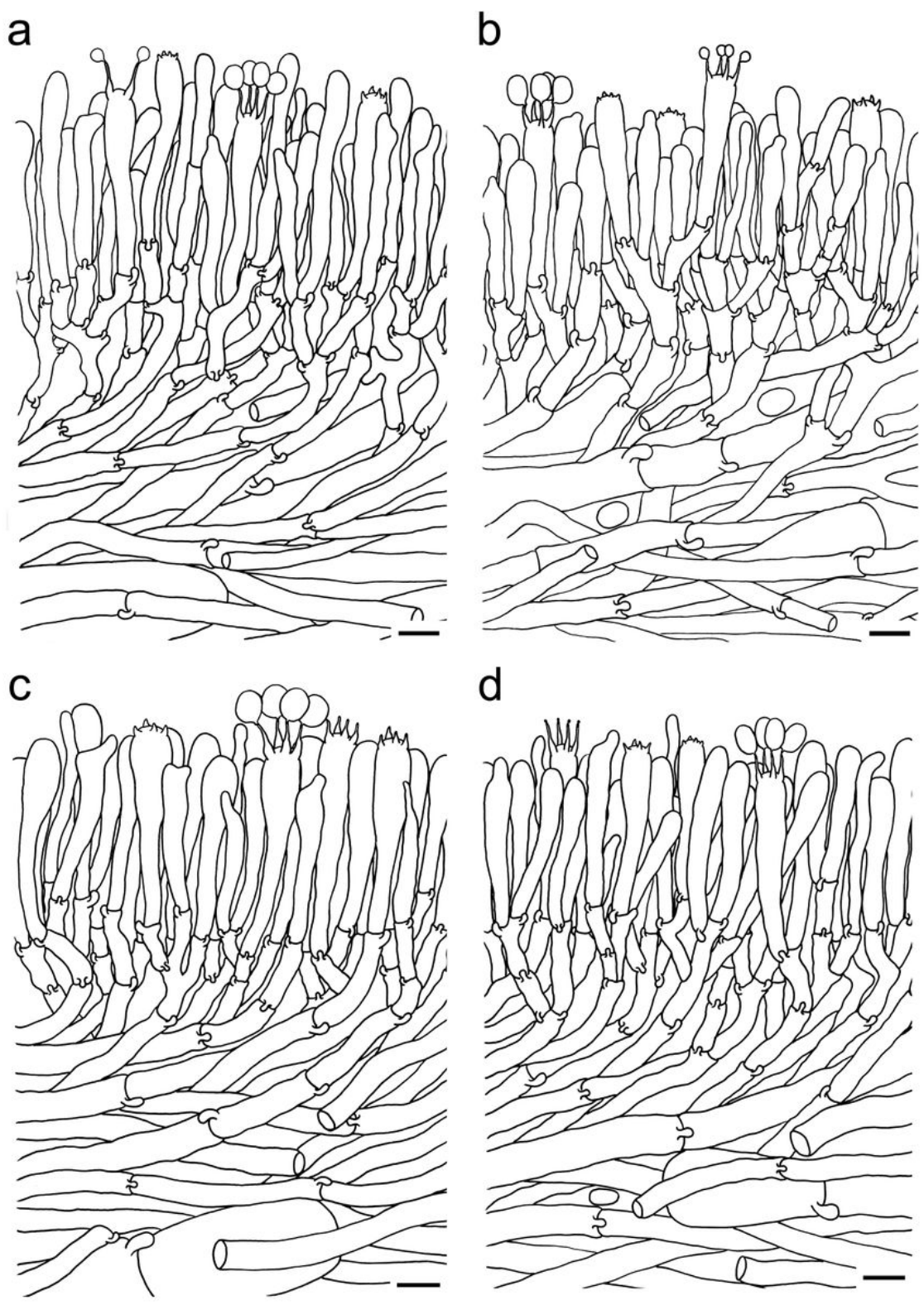

d

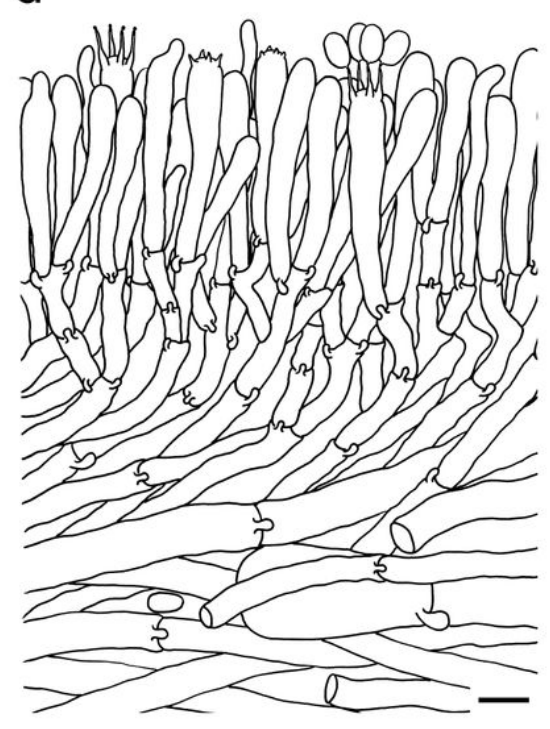

\section{Figure 9}

Hymenium (including basidia, pleurocystidia and lamellar trama) of Hygrophorus russula complex. a. H. deliciosus (HKAS 54510); $b$. H. orientalis (HKAS 71845); c. H. qinggangjun (MHKMU L.P. Tang 1683); d. H. yunnanensis (MHKMU H.Y. Huang 322 ). Bars $=10 \mu \mathrm{m}$ 

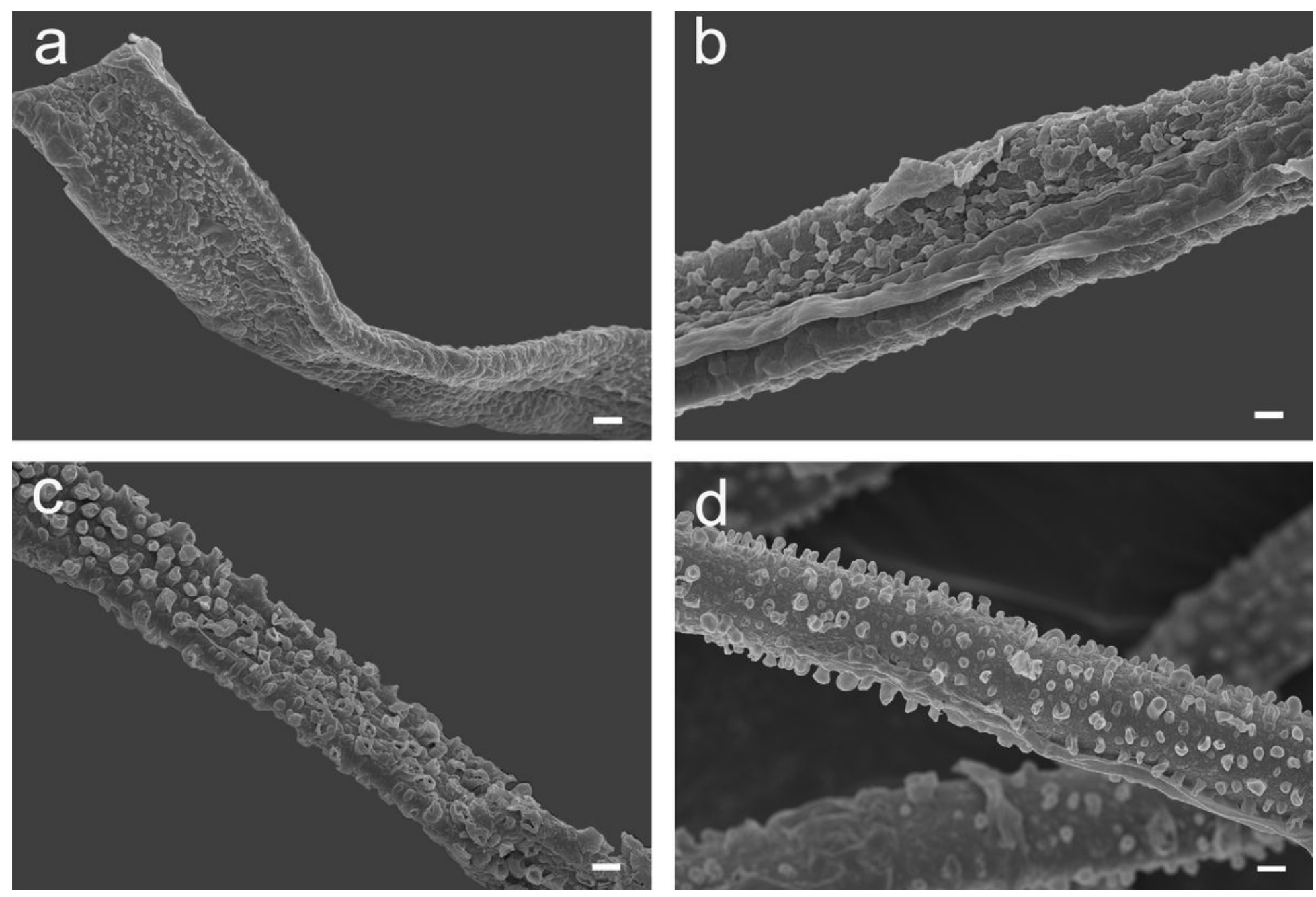

\section{Figure 10}

Basal mycelial hyphae of Hygrophorus russula complex under SEM. a. H. deliciosus (MHKMU S.D. Yang 70); b. H. orientalis (HKAS 75586); c. H. qinggangjun (MHKMU L.P. Tang 1683); d. H. yunnanensis (MHKMU S.D. Yang 12). Bars = $1 \mu \mathrm{m}$ 

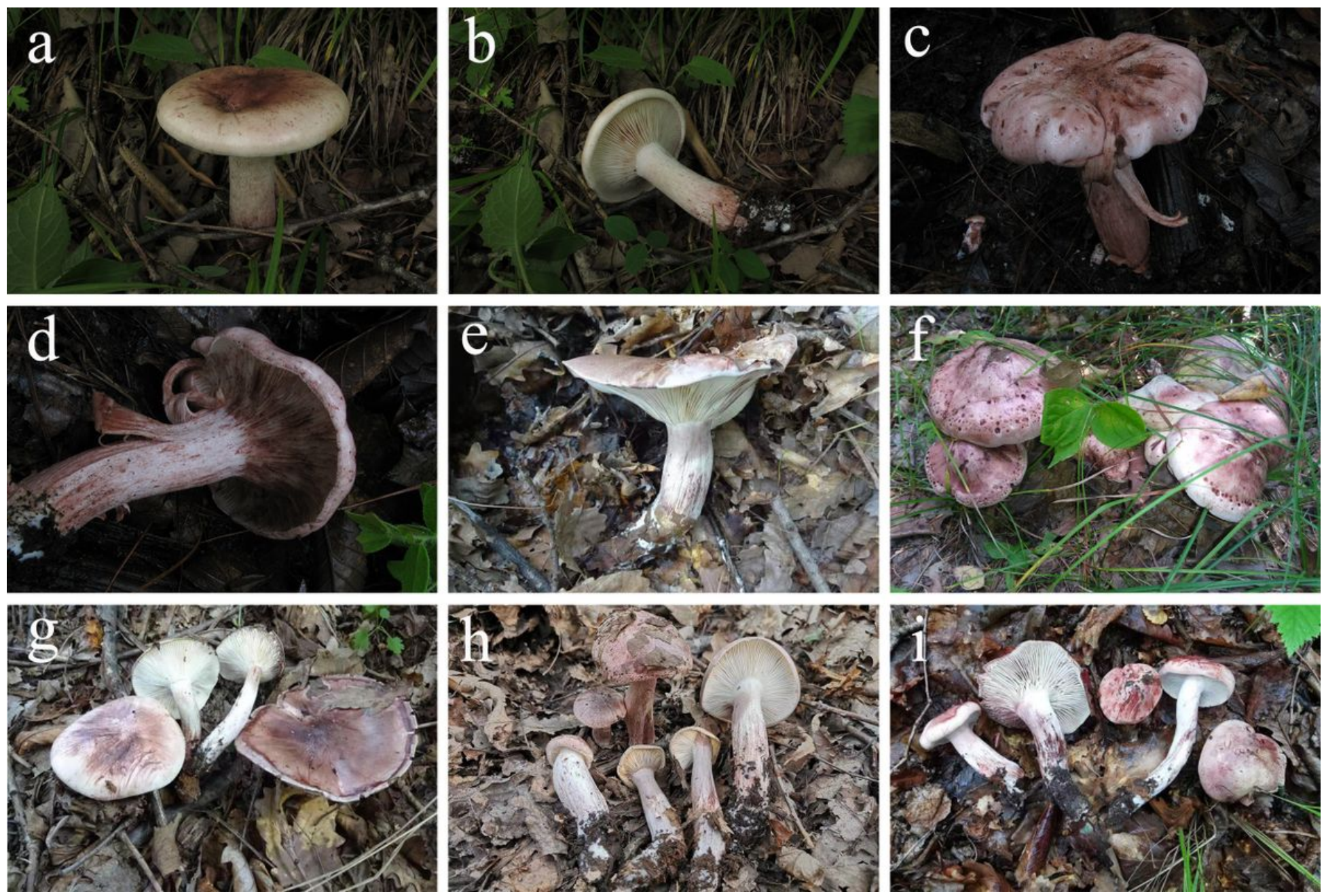

Figure 11

Basidiomata of Hygrophorus orientalis. a, b. from HKAS 75586; c-d. from HKAS 58741; e, g-h. from CFSZ 20884; f. from MHKMU H.Y. Huang 472 (a-d photos by Q. Cai; e, g-h photos by T.Z Liu; f photo by B. Wang) 

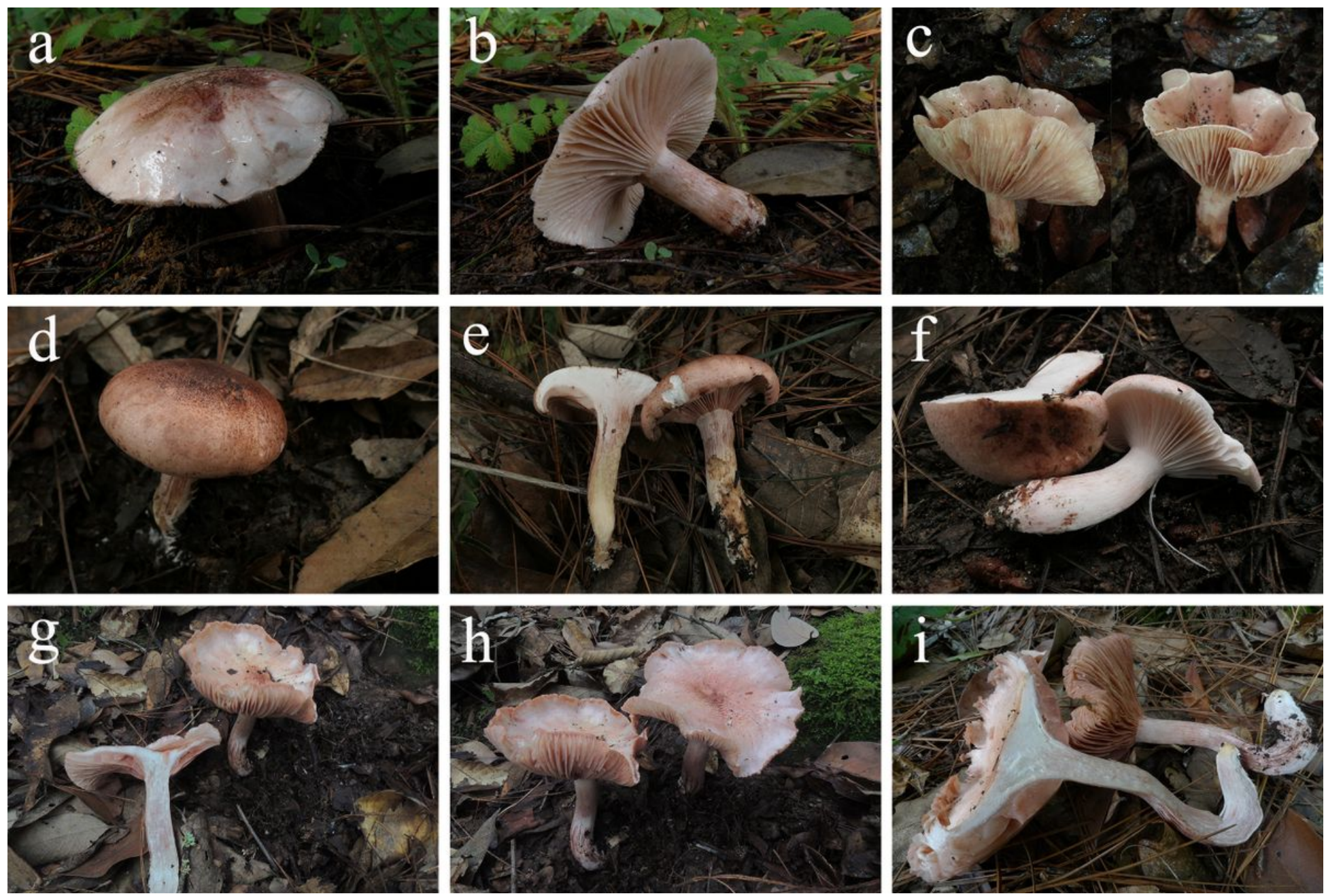

\section{Figure 12}

Basidiomata of Hygrophorus qinggangjun. a, b. from HKAS 68397; c. from Q. Zhao 447; d-e. from MHKMU M. Mu 436; f. from MHKMU M. Mu 464; g-h. from MHKMU S.D. Yang 20; i. from MHKMU L.P. Tang 1683 (a, b photos by X.T. Zhu; c photo by Q. Zhao; d-f photos by M. Mu; g-h photos by S.D. Yang; i photo by L.P. Tang) 

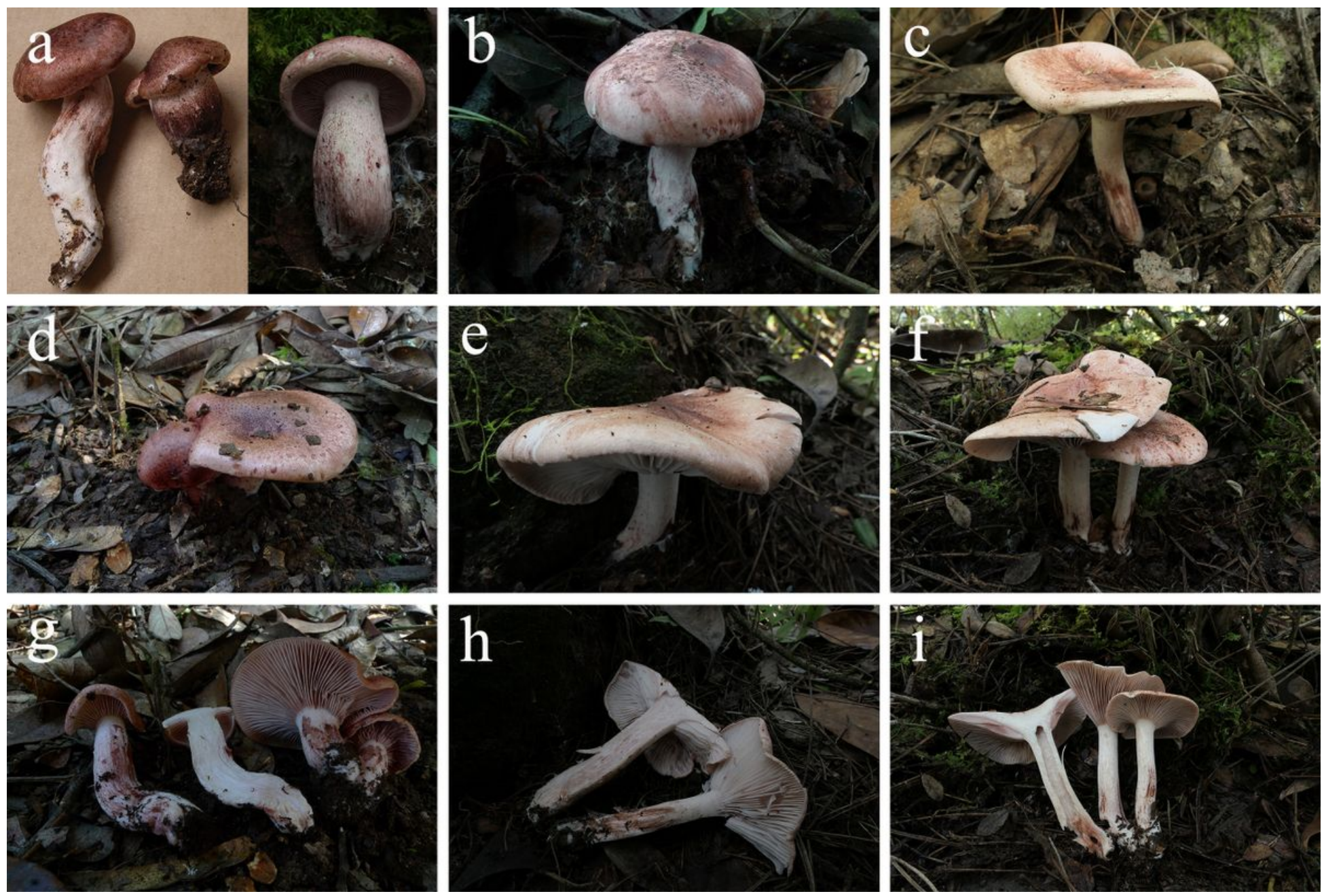

\section{Figure 13}

Basidiomata of Hygrophorus yunnanensis. a. left from HKAS 50442, right from MHKMU J. Zhao 52; b. from MHKMU L.P. Tang 2751; c. from MHKMU H.Y. Huang 971; d, g. from MHKMU L.P. Tang 2772; e, h. from MHKMU H.Y. Huang 316; f, i. from MHKMU H.Y. Huang 322 (a left photo by Y.C. Li, right photo by J. Zhao; b, d, g photos by L.P. Tang; c, e, f, h, i photos by H.Y. Huang) 


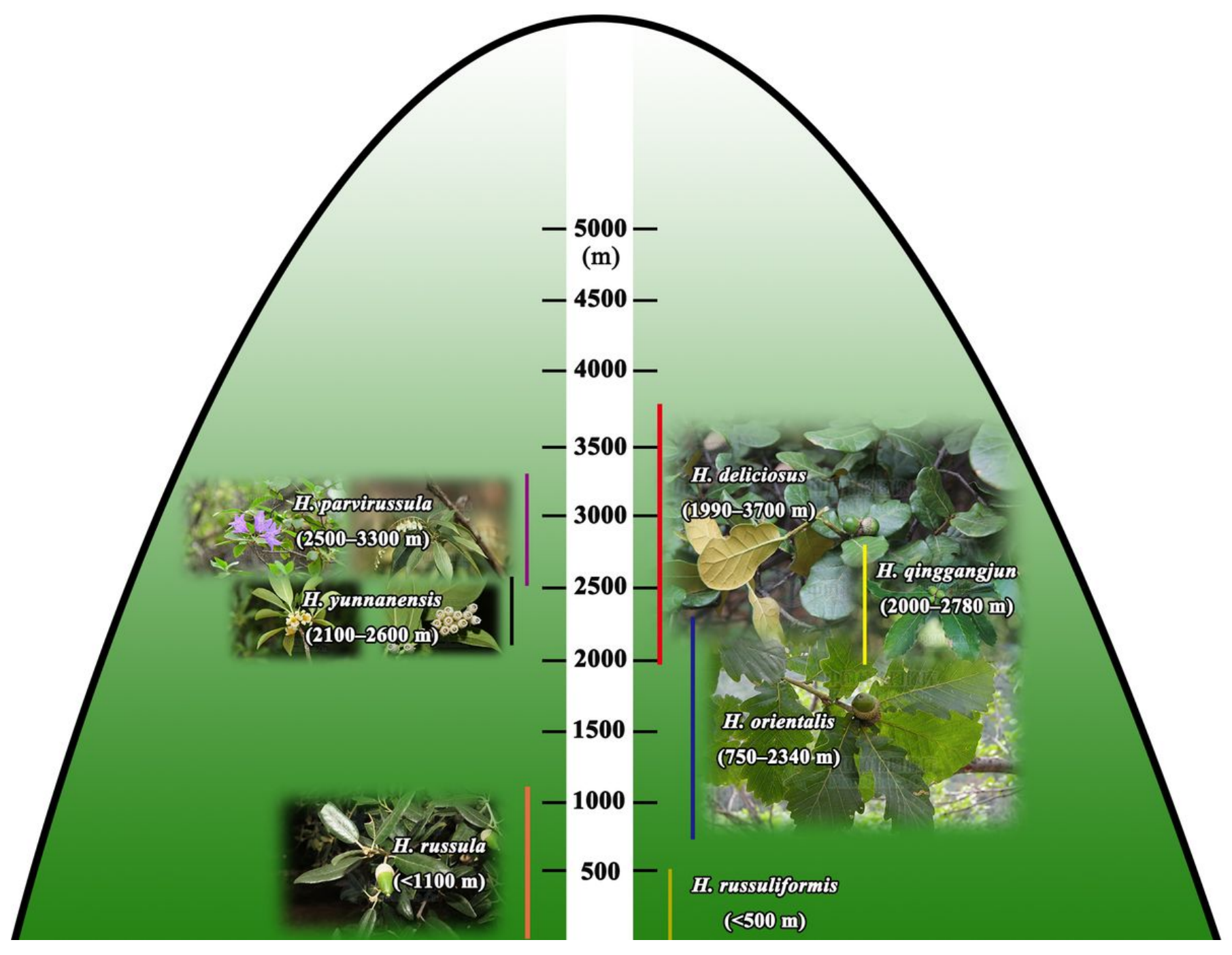

Figure 14

Distribution elevation and host plants of Hygrophorus russula complex. [The host plants' photos from the website: Plant Photo Bank of China (PPBC)]

\section{Supplementary Files}

This is a list of supplementary files associated with this preprint. Click to download.

- H.russulacomplexITSLSU.nxs

- H.russulacomplexITS.nxs

- H.russulacomplexLSU.nxs 